\title{
RUSIJOS FEDERACIJOS PREZIDENTO \\ V. PUTINO NARATYVU IDEOLOGINIAI \\ MECHANIZMAI LIETUVOS \\ INTERNETINĖJE ŽINIASKLAIDOJE
}

Prof. DR. Jolanta Zabarskaité

Kazimiero Simonavičiaus universitetas

Kazimieras Simonavičius University

Dariaus ir Girèno g. 21, LT-02189, Vilnius

El.paštas jolanta.zabarskaite@ksu.lt

\section{Santrauka}

Šiame straipsnyje nagrinejami semantiniai kalbos procesai, kurie gali daryti ịtaka vieno ar kito reiškinio, proceso, asmenybès suvokimui ir vertinimui. Aptariamos kalbos ir mastymo santykio problemos, kalbos vaidmuo formuojant pasaulevaizdi, pakitusios ir kitaip organizuojamos kalbos funkcijos XXI amžiuje, galimas kalbos semantiniu procesu panaudojimas hibridiniuose karuose. Keliamas klausimas, ar gebama atpažinti nesąmoninga ir (arba) pusiau samoninga kalbos suvokimo reiškini, kai per žodžiu reikšmiu ir asociacijų semantinius mechanizmus sukuriama ideologine implikacija, daranti ịtaką reiškinio, asmenybès, ịvykio vertinimui. Ideologinès implikacijos atsiradimo ir veikimo per konkretaus žodžio semantika mechanizmams atskleisti pasirinkta žiniasklaida, nes ji yra viena svarbiausiu viešosios kalbos erdviu. Atlikta atvejo analize - ivertintas leksikos ir semantikos vaidmuo kuriant naratyva apie Lietuvai reikšmingos geopolitinès kaimynès - Rusijos - prezidenta Vladimira Putina informaciniuose portaluose www.delfi.lt, www.lrytas.lt, www.15min.lt. 
Reikšminiai žodžiai: kalbos funkcijos; ideologinès implikacijos; semantiniai procesai; naratyvas; hibridiniai karai; naujosios medijos; internetinè žiniasklaida.

\section{Ivadas}

Straipsnyje nagrinėjama, kaip tekstuose veikia konkretūs žodžiai, kurių semantika sukuria ideologinių implikacijų, veikiančių reiškinio, asmenybès, îvykio vertinimą.

Kiekvienas reiškinys šiuolaikinėje sociokultūrinèje aplinkoje turi savo naratyvą (naratyvus). Kuriant naratyvą labai svarbus yra kalbos vaidmuo $^{1}$. Naratyvą formuoja vartojama leksika, semantinės konstrukcijos, tropai, stilistinès priemonès. Todèl analizuojant, kaip per žodžius veikia ideologinès implikacijos, atlikta naratyvinė kalbinė analizè.

Ideologinių implikacijų per konkretų žodị su(si)kūrimo ir veikimo mechanizmams atskleisti pasirinkta žiniasklaida, nes ji yra viena svarbiausių viešosios kalbos erdvių. Žiniasklaidoje viešosios nuomonès laukas ir formuojamas, ir atspindimas. Kalbos vaidmuo, kaip parodysime šiame straipsnyje, išsiplečia, nes kalba veikia ne tik kaip komunikacinis įrankis, bet ir kaip svarbus elementas sudetingame ideologijų formavimo procese.

Straipsnio tikslas yra nustatyti, kaip per konkrečius žodžius sukuriamos ideologinès implikacijos ir formuojami prieštaringi Rusijos prezidento V. Putino naratyvai. Remiamasi prielaida, kad viešojoje erdvèje veikia vienas kitam priešingi naratyvai: Putinas - demokratijos raidos Europoje antagonistas ir Putinas - herojus. Ši prielaida patvirtinama išanalizavus atsitiktinai parinktus tekstus apie V. Putiną informaciniuose portaluose www.delfi.lt, www.lrytas.lt, www.15min.lt.

Plačiau žr. Dijk, van T. A. Narrative macro-structures. Logical and Cognitive Foundations. A Journal for Descriptive Poetics and Theory of Literature. Vol. 1 (1976), p. 547-568. 


\section{Žiniasklaidos kalbos moksliniai tyrimai Lietuvoje}

Žiniasklaidos kalbos (toliau - ŽK) klausimai tarp lietuvių kalbotyroje tiriamų problemų nèra labai populiarūs. Be abejonès, analizuojant stilius, žanrų skirtumus, kalbos variantiškumą ŽK specifika ir ypatumai ịtraukiami ị bendrąji probleminị lauką. Specialiai ŽK temai skirtų mokslinių tyrimų nèra daug. Mokslinius straipsnius, skirtus ŽK, pagal analizuojamų problemų tipus galima suskirstyti $i \mathfrak{~ k e l e t a ̨ ~ g r u p i u ̨ : ~}$

1. Mokslinis dèmesys daugiausia skiriamas ŽK stiliaus klausimams, ypač emocinei ekspresinei leksikai, frazeologijai, specialiajai leksikai ir terminologijai. Pavyzdžiui, viena žymiausių Lietuvoje stilistikos ir retorikos tyrëjų Regina Koženiauskienè nagrinèjo frazeologizmų transformaciją žiniasklaidoje ${ }^{2}$. Frazeologizmų vieta, reikšmė, vaidmuo, funkcijos žiniasklaidoje - probleminis klausimas, kuris domina ir vertimo problemas tiriančius mokslininkus 3 . Specifinès etnoleksikos transformacijos yra atkreipusios tautosakos specialistų dèmesị, jie žiniasklaidą tyrinèjo kaip semantinę terpę, palankią mįslių žodžių metaforikai atsiskleisti ${ }^{4}$. Šio tipo tyrimuose paprastai taikomi tradiciniai lingvistikos ir filologijos metodai, o jų rezultatai gali būti toliau panaudojami lingvistiniame, filologiniame ir taikomajame žiniasklaidos kalbos pažinimo ir tobulinimo lauke. Tai tyrimai, neišeinantys iš apibrèžto lingvistikos objektų lauko.

2. Kita, ko gero, pati žinomiausia tradicinė kalbos tyrimų žiniasklaidoje sritis - sakytinès žiniasklaidos stilius, tartis ir kirčiavimas. Pastaraisiais metais vyksta moksline polemika tarp sociolingvistų ir klasikinės retorikos bei stilistikos specialistų dèl sakytinės žiniasklai-

2 Koženiauskienè, R. Perkurtos frazeologijos žaismas žiniasklaidoje. Kalbos kultūra. Nr. 86. Vilnius, 2013, p. 149-166.

3 Baranovskaja, I.; Skorupa, P. Some aspects of English idiom in traditional media classification and the problem of translation into Lithuanian. Santalka: filologija, edukologija. T. 21, Nr. 1. Vilnius, 2013, p. 5-12.

4 Kensminienè, A. Mịslių suvokimo raida: nuo refleksijos tradicinèse mịslèse iki termino metaforinio išskydimo masinèse žiniasklaidos priemonèse. Tautosakos darbai. T. 54. Vilnius, 2017, p. 26-48. 
dos stiliaus, tarties ir kirčiavimo reguliavimo poreikio, tikslingumo, tikslo bei realios sociolingvistinès situacijos ${ }^{5}$. Mokslinè polemika leidžia klasikinę uždarą žiniasklaidos kalbos tyrimų problematiką kalbos tyrimai - kalbai išplèsti $\mathfrak{i}$ ŽK ir visuomenès santykių tyrimus. Tačiau sociolingvistikos metodai ir tyrimų rezultatai taip pat orientuoti ị uždarą kalbos problematiką.

3. Pastaraisiais metais suklestèję kognityviniai mokslai paskatino ŽK tyrimų dinamiką. Parengti pirmieji darbai, kuriuose žiniasklaida tiriama kaip sociokultūrinis kontekstas ir (arba) procesas, kuriantis sociokultūrinius konstruktus - ịvaizdị, ịvykị, emociją ir pan., ir reprezentuojamas kalba ${ }^{6}$. Kognityviniu požiūriu ŽK analizuojama leksinè-semantinė sistema ${ }^{7}$. Šio tipo tyrimais atveriama erdvė žiniasklaidos kalbos, jos santykio su realiu gyvenimu stebėsenai, vertinimui ir keitimui tarpdalykinių metodologijų lauke.

4. Kognityvinis požiūris į ŽK suponuoja ir dar vieną tyrimų kryptị - jos poveikio adresatui mokslinę problematiką. Tokio pobūdžio mokslo darbų taip pat nèra daug. Kalbininkų dèmesị atkreipe žiniasklaidos antraštès ${ }^{8}$. Medijų tyrèjai yra domejjęsi formos ir poveikio santykių analize?

5 Čičirkaitè, R. Radijuj ir televizijoj gal net vilnietiškai jie kalba. Sakytinės žiniasklaidos ir Vilniaus kalbos nekirčiuotų kintamujų /i:/, /u:/, /e:/, /o:/, /æ:/ ir /a:/ akustiné analizè. Taikomoji kalbotyra. T. 8 [elektroninis išteklius]. Vilnius, 2016, p. 107-135; Smetonienè, I. Žiniasklaidos kalba ir stilius: tartis ir kirčiavimas [elektroninis išteklius]. 2014-d.,1 pdf, 48 p.

6 Senvaitytè, D.; Gražytè, R. Senają lietuvių religiją nusakanti terminija bei jos kontekstas elektroninejje Lietuvos žiniasklaidoje. Žmogus kalbos erdvèje. Nr. 6. Kaunas, 2010, p. 479-488.

7 Aleksaite, A. Emocinè-ekspresinė leksika kaip kalbinė politiku portretu kūrimo priemonè naujienų portale Delfi.lt. Bendriné kalba. T. 89 [elektroninis išteklius]. Vilnius, 2016, 1 pdf, 15 p.

8 Liepinytė-Kytrienè, D. Antraščių-faktinių teiginių poveikio priemonès interneto portale Delfi.lt. Taikomoji kalbotyra. T. 2 [elektroninis išteklius]. Vilnius, 2013, $1 \mathrm{html}$.

9 Mažylè, J. Naujienų atrankos įtaka publikacijos pateikimo būdui ir formai. Medijos, žiniasklaida, žurnalistika tradicinejje ir tinklaveikos visuomeneje. Kolektyvinè monografija, red. Ž. Pečiulis, Vilnius, 2012, p. 165-171. 
Lietuvių kalbos poveikis aktyvios kalbinès bendruomenès sąmonei, o per ją ir realiems gyvenimo procesams nèra tirtas. Nèra nagrinèta, kokie kalbos mechanizmai formuoja viešąą nuomonę diskurso lygiu (tiriama tik tai, kokios kalbos priemonès geriausiu būdu perteikia faktus ir jų interpretaciją, požiūrị, emociją, sentimentus ir t. t.). Taip pat nèra tirta, kaip nesąmoningai arba pusiau sąmoningai teksto suvokimo procesuose veikia žodžių semantika, sukurdama ideologinių implikacijų, ne visada sutampančių, o kartais ir prieštaraujančių teksto turiniui.

Tokios krypties tyrimai yra labai reikalingi ir aktualūs netgi valstybès saugumo požiūriu, nes gali būti panaudoti hibridiniuose karuose, kuriuose vertybiniu požiūriu siekiama iškreipti piliečių sąmonę. Vienas žymiausių kalbos ir ideologijos ryšio tyrèjų Tuenas A. van Dijkas teigia, kad „Ideologinè diskurso analizè, aiškiai nurodant sakinio ar teksto fragmento reikšmes, gali būti galinga kritinio tyrimo priemone.." ${ }^{10}$

Kad ideologinių implikacijų, sukuriamų per žodžius, procesai būtų atpažįstami, pirmiausia reikia suvokti, ką reiškia kalbos ir mąstymo ryšys ir kokius sociokultūrinius bei lingvistinius reiškinius jis generuoja.

\section{Kalbos ir mąstymo ryšys}

Jei kalbą vertintume tik kaip komunikacijos įrankį, jos funkcionalumas apsiribotų informacijos perdavimo būdais ir priemonėmis. Iki XXI amžiaus taip ir buvo. Pagrindinès kalbos funkcijos buvo reprezentatyvinè referencinè ir komunikacinè ${ }^{11}$. Atsiradus internetui, kuriame virtualioje erdveje susipynè materialus ir idealus pasaulis, prasidejo procesai, kuriuos genialus Marshallas McLuhanas nuspejo taip: „Nauja elektros technologija, mūsų juslèmis ir nervais apjuosianti visą žemès rutulị, turès lemiamos įtakos kalbos ateičiai. Elektros

${ }^{10}$ Dijk, van T. A. Ideology and discourse. A Multidisciplinary Introduction. Los Angeles, London, New Delph, Singapore, Washington DC: Sage, 2011, p. 47.

${ }^{11}$ Karaliūnas, S. Kalba ir visuomene. Psichologiniai ir komunikaciniai kalbos vartojimo bruožai. Vilnius, 1997, p. 132-136. 
technologijai žodžių reikia ne daugiau nei kompiuteriui skaitmenų. Elektra rodo kelią i pačios sąmonès procesų pratęsimą pasauliniu mastu ir be jokios verbalizacijos. " ${ }^{12}$ Iš tiesų, skaitmeninès aplinkos sukurta multimedijų priemonių ívairovẻ komunikacinę kalbos funkciją iš vienintelès galimos redukavo ì vienos iš kelių lygit $\mathfrak{i}^{13}$. Bet M. McLuhanas nenumatè, kad virtualioje erdveje mus supantis realusis pasaulis buvo semantizuotas ir dèl to sustiprèjo vadinamoji mentalinė kognityvinè kalbos funkcija, t. y. išaugo kalbos vaidmuo pasaulèvokos ir pasaulèkūros procesuose ${ }^{14}$.

Virtualus pasaulis ne tik pakeitè žiniasklaidos formas, bet ir sukūrẻ naujų komunikacijos būdų, tokių kaip daugybinè sąveika, kai asmuo vienu metu apdoroja ịvairios pateikties ir turinio informaciją ${ }^{15}$. Būtent todèl visuomenè, ịvertinusi naujųjų medijų dominavimą, intuityviai suvokè, kad jų poveikis yra gerokai stipresnis ir reikšmingesnis, negu atrodo iš pirmo žvilgsnio.

Skaitmeninė erdvè turi savybę būti daugiafunkcè, o tai leidžia ir kalbos generuojamas prasmes susieti ne tik linijiniais, bet ir 3D ryšiais. Dèl to vienu metu kalbos vartotojo suvokimą gali veikti keletas kalbos prasminių laukų, kurie reiškia skirtingus (kartais net prieštaringus) dalykus.

Šiuos tris veiksnius:

1. kad pasaulis virtualioje erdveje yra semantizuotas, todèl kuriamas ir tvarkomas kalbos priemonemis;

2. kad ịsigali naujosios medijos, aktyviai dalyvaujančios realiuose pasaulèkūros ir pasaulèvokos procesuose;

3. kad kalba virtualioje erdveje gali vienu metu generuoti keletą raiškos planų -

McLuhan, M. Kaip suprasti medijas. Vilnius, 2003, p. 91.

13 Šiuolaikinès technologijos sukuria visas galimybes komunikuoti ir vaizdais.

${ }^{14}$ Karaliūnas, S. Kalba ir visuomene. Psichologiniai ir komunikaciniai kalbos vartojimo bruožai. Vilnius, 1997, p. 169-242.

15 Ophir, E.; Nass, C.; Wagner, A. D. Cognitive control in media multitaskers. Proceedings of the National Academy of Sciences of the United States of America. 2009. 
labai svarbu suvokti, vertinant per konkrečius žodžius atsirandančių ideologinių implikacijų susiformavimo ir veikimo būdus. Pavyzdžiui, tekste (diskurse) yra rašoma apie Vladimiro Lenino revoliuciją Rusijoje kaip teroristinị valstybės perversmą, bet bolševikų antagonistai - dvarininkų socialinè klasė - nesąmoningai (arba sąmoningai, jei teksto kūrẻjas turi tikslų sukelti adresatui abejonę neigiamu V. Lenino terorizmo vertinimu) pavadinami sovietiniu ideologiniu terminu išnaudotojai. Taip siunčiami du priešingi semantiniai signalai: Lenino revoliucija blogis, nes tai teroristinis perversmas (istoriškai ir vertybiškai visuotinai priimtas Lenino revoliucijos naratyvas demokratineje visuomeneje), ir Lenino revoliucija - teigiamas reiškinys, nes sustabde neigiama reiški$n i$ - išnaudojima (autoritarinio mąstymo naratyvas, sukuriamas per žodžio išnaudotojai ideologines implikacijas). Pats reiškinys - kalbos geba generuoti keletą prasminių laukų, nèra nauja kalbos funkcija. Tačiau naujosios medijos šiai funkcijai sukuria išskirtinai palankią terpę.

Lingvistiškai tai reiškia semantikos tyrimų posūkị kognityvizmo kryptimi. Yra „du būdai atlikti kognityvinès semantikos tyrimus: tirti leksinius vienetus, susietus su kitais leksiniais vienetais, ir tirti leksinius vienetus, susietus su „realiu pasauliu“"16. Kalbinių procesų ir realaus gyvenimo raidos sankirta pasireiškia per dvi - kalbinę ir realaus gyvenimo - plotmes:

1. Kalbinejje plotmèje ypatingą vaidmenị vaidina daugiapakopès prasminès struktūros analizé;

2. Kalbinio pasaulèvaizdžio ir realaus gyvenimo sankirtos plotmejje galima analizuoti kalbos ịtaką realybejje vykstantiems procesams.

Semantinè struktūra, daranti poveikị realiam gyvenimui, susideda iš tokių elementų: žodžio reikšmè ${ }^{17}$ / sąvoka / konotacijos (sentimentai) / aukščiausia suvokimo pakopa - prasmè.

${ }^{16}$ Baker, C. What Can Words Mean? Encyclopedia of Cognitive Science. Oxford: Macmillan Publishers, 2000.

${ }^{17}$ Kartais tai gali būti kolokacija arba frazeologizmas. 


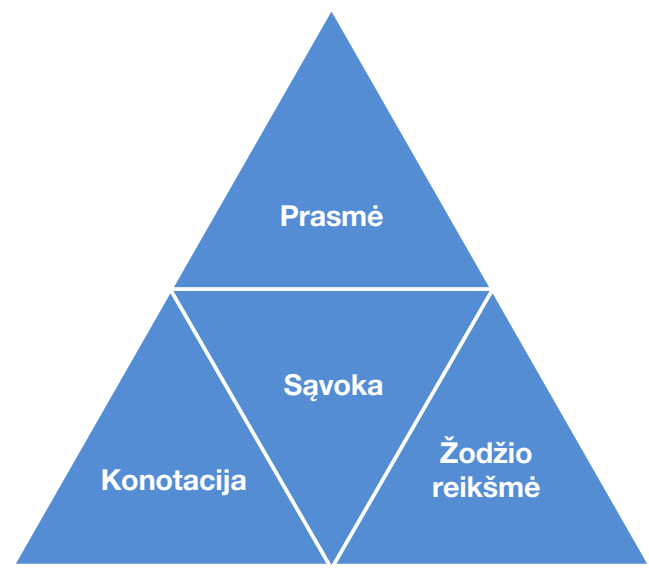

1 paveikslas. Semantinè struktūra

Dèl šių semantinių elementų žodis potencialiai gali generuoti ideologinių implikacijų.

Ideologinių implikacijų per žodị generavimo mechanizmai ir naratyvo kūrimas

Žymus kalbos filosofas Ludwigas Wittgensteinas „Loginiame filosofiniame traktate“ rašè: „Mano kalbos ribos žymi mano pasaulio ribas." Kalbos riba iš esmès yra žodžio reikšmés riba, nes kalbos sistemoje žodis laikomas pagrindiniu kalbos vienetu. Žodžiai yra tikrovès referencijos ir realaus gyvenimo kalbinès reprezentacijos pamatas, ant kurio kuriama kalbinè pasaulèvoka ir pasaulèkūra.

Kiekvienas žodis turi platesnę referencijos / reprezentacijos dimensiją - sąvoką. Tai - sudètinga, kintanti semantinè struktūra, susiformavusi iš patyrimo / asociacijų / žinojimo / žinių. Kalbos veikimas „realiame gyvenime“ labiausiai susietas su šia semantinès hierarchinès struktūros pakopa. Sąvoka turi ir emocinio tikrovès vertinimo (sentimentų, konotacijos) potencijos. 
Kalba - tai „juodoji dèže“, t. y. mes objektyviai gauname „ęeinančią“ ir „išeinančią“ informaciją ir galime tik nuspèti, kokie procesai vyksta neuropsichologiniu kalbos suvokimo lygmeniu. Galime empiriškai patvirtinti, kad aktyvūs kalbos vartotojai per konkretaus žodžio semantiką ir asociatyvius ryšius su kitais žodžiais, reikšmèmis, konotacijomis, asociacijomis bei sentimentais geba generuoti aukščiausią kalbos suvokimo pakopą - prasmę. Kognityvistai teigia, o neuromokslininkai patvirtina, kad kalbos vartotojai naudoja neribotą skaičių ryšių, kai nesąmoningai ir (arba) pusiau sąmoningai mentalinejje struktūroje ịtinklina kiekvieną "gaunamą ir atiduodamą" žodị su jo leksiniu, sintaksiniu, socialiniu ir psichologiniu junglumu. Paviršineje prasmių lauko pakopoje kalbos vartotojas sąmoningai kuria prasmes, nes tikslas yra perteikti informaciją. Tačiau kai kurios prasmės gali atsirasti nesąmoningai (arba netiesiogiai), kai vieno ar kito žodžio semantika ,juodojoje dèžèje“ - kalboje - pakliūva ị iš anksto nenumatytų (arba specialiai parinktų) ryšių lauką, o tai gali sukurti ideologinių implikacijų, kurios atsikleidžia konkrečiuose socialiniuose ir psichologiniuose kontekstuose ir veikia teksto suvokimą.

Per teksto suvokimą žodžių sukuriamos ideologinès implikacijos dalyvauja kuriant ir palaikant naratyvą. Jo sąvoka mokslinejje literatūroje apibrèžiama ịvairiai: „Egzistuoja daug ịvairių naratyvo apibrèžimų (daugiau ar mažiau žyminčių objekto ribas) ir daug atsakymų i klausimą - kas yra naratyvas? Vieni teoretikai ir tyrinètojai naratyvą apibrèžia kaip verbalinị kūrinị, smulkiai pasakojantị vieną arba ne vieną îvykį, kiti jị apibrèžia kaip bet kokią ịvykių reprezentaciją." ${ }^{18}$ Žymus prancūzų naratologas Geraldas Prince’as sako, kad „objektas yra naratyvas, jei jis yra logiškai nuosekli bent dviejų asinchroninių ìvykių (arba būsenos ir îvykio), kurie nesuponuoja arba nenumano

18 Prince, G. Apie šiuolaikinę naratologiją. Žmogus ir žodis. T. 16, Nr. 2. Vilnius, 2014, p. 106-107. 
vienas kito, reprezentacija"19. Naratyvas tiriamas įvairiais pjūviais: socialiniu, istoriniu, literatūriniu, antropologiniu, net galios ${ }^{20}$ ir t. t. Kalbinè analizė gali atskleisti teksto santykị su vienu ar kitu apibendrintu kokio nors objekto / ívykio / veikejo naratyvu.

Šiame straipsnyje konkretaus atvejo analizei pasirinktas Rusijos prezidento V. Putino naratyvas Lietuvos internetinèje žiniasklaidoje. „Realiame gyvenime“ matome esant du antonimiškus V. Putino naratyvus, kuriuos apibendrintai galima pavadinti taip: Putinas - demokratijos raidos Europoje antagonistas ir Putinas - herojus. Keliamas klausimas, ar šie naratyvai veikia Lietuvos žiniasklaidoje. Jeigu veikia, tai kokiomis leksinemis priemonèmis jie yra kuriami ir palaikomi?

\section{Atvejo tyrimas ir gauti rezultatai}

Tekstuose, pasirenkant leksiką, sukuriamas daugiapakopis prasmių laukas, kuriame pateikiami reiškiniai ir (arba) ìvykiai, asmenų vertinimas gali turèti ne tik akivaizdžiai identifikuojamų prasmių (kq autorius / informacijos šaltinis norèjo pasakyti?), bet ir prasmių, atsiradusių dèl nesuvaldytos žodžių ir žodžių junginių semantikos, sąvokos ryšių su „realiu gyvenimu“, sociokultūrinių ir politinių asociacijų, viešų sentimentų. Žodžiai gali sukurti ideologinių implikacijų neprognozuotam / nenorimam ( $k a$ autorius / šaltinis pasaké v. s. mane / mus ne taip suprato) teksto suvokimui.

Kaip jau buvo minèta, dèl ịvairių politinių, geopolitinių, sociokultūrinių priežasčių, kurių vertinimas nèra šio straipsnio objektas, viešojoje erdvejje Lietuvoje atpažistami du naratyvai apie V. Putiną:

1. Viešas naratyvas, atliepiantis europines vertybes ir Lietuvos politinę kryptị, Putinas - demokratijos raidos Europoje antagonistas. Naratyvo struktūros kategorijomis kalbant, Putinas priešas.

19 Ten pat.

${ }^{20}$ Daya, S.; Lau, L. Power and narrative. Narrative Inquiry. Vol. 17. Amsterdam, Philadelphia, 2007, p. 1-13. 
2. Neviešas naratyvas, Rusijos propagandos skleidžiamas, ị viešąją erdvę brukamas turint tikslą grąžinti visuomenès mąstymą ì kontrolès ribas. Naratyvo struktūros kategorijomis kalbant, Putinas - herojus.

Diskurso analitikai teigia, kad ideologinès implikacijos sukuriamos per priešpriešą: „apie saviškius (mus) - kalbama gerai“, apie antagonistus (juos) - „blogai“21. Toks principas tinka ir naratyvui, nes šis veikia per diskursą ${ }^{22}$. Paprasčiau sakant, teigiamos / neigiamos leksikos vartojimas sociokultūriniuose ir psichologiniuose kontekstuose gali sukurti ideologinių implikacijų.

Siekiant objektyvumo visiškai atsitiktinai pasirinkti tekstai, kurių antraštėse buvo paminètas V. Putinas. Imtys - du laikotarpiai: 2016 m. kovo mėnuo ir 2019 m. kovo ménuo. Publikacijų skaičius ir šaltiniai pateikti 1 ir 2 lenteleje:

1 lentele. Publikacijų skaičius ir šaltiniai $2016 \mathrm{~m}$. kovo mėnesi

\begin{tabular}{|c|c|c|c|}
\hline & Delfi.lt & Lrytas.lt & 15 min.lt \\
\hline $\begin{array}{l}\text { Antraščių, } \\
\text { kuriose minima } \\
\text { V. Putino pa- } \\
\text { vardè, skaičius }\end{array}$ & 7 & 15 & 8 \\
\hline $\begin{array}{l}\text { Portale panau- } \\
\text { doti šaltiniai ir } \\
\text { jų skaičius }\end{array}$ & $\begin{array}{l}\text { „Bloomberg“1 } \\
\text { Leonid Bershidsky / } \\
\text { „Bloomberg“1 } \\
\text { Evgenia Pismennaya, } \\
\text { Anna Andianova / } \\
\text { „Bloomberg“ 1 } \\
\text { BNS 2 } \\
\text { Reuters 1 } \\
\text { Rimvydas Valatka 1 }\end{array}$ & $\begin{array}{l}\text { Lrytas } 6 \\
\text { BNS ir Lrytas } \\
\text { inf. } 7 \\
\text { BNS / Interfax / } \\
\text { Lrytas 1 } \\
\text { BNS / APF / } \\
\text { Lrytas } 1\end{array}$ & $\begin{array}{l}\text { BNS } 5 \\
\text { Reuters } 1 \\
\text { Partnerio turinys } \\
1 \\
\text { Šaltinis nenuro- } \\
\text { dytas } 1\end{array}$ \\
\hline
\end{tabular}

${ }^{21}$ Dijk, van T. A. Ideology and discourse. A Multidisciplinary Introduction. Los Angeles, London, New Delph, Singapore, Washington DC: Sage, 2011, p. 44.

${ }^{22}$ Dijk, van T. A. Narrative macro-structures. Logical and Cognitive Foundations. A Journal for Descriptive Poetics and Theory of Literature. Vol. 1 (1976), p. 547-568. 
2 lentelè. Publikacijų skaičius ir šaltiniai 2019 m. kovo mẻnesį $i^{23}$

\begin{tabular}{|c|c|c|c|}
\hline & Delfi.lt & Lrytas.lt & $15 \mathrm{~min} . l \mathrm{t}$ \\
\hline $\begin{array}{l}\text { Antraščių, } \\
\text { kuriose minima } \\
\text { V. Putino pavar- } \\
\text { dè, skaičius }\end{array}$ & 10 & 1 & 25 \\
\hline $\begin{array}{l}\text { Portale skel- } \\
\text { biamų tekstų } \\
\text { šaltiniai ir (arba) } \\
\text { autoriai ir tekstų } \\
\text { skaičius }\end{array}$ & $\begin{array}{l}\text { Rima Janužytė } 1 \\
\text { Olegas Jerofejevas } 1 \\
\text { LRT } 1 \\
\text { Egle Samoškaitè } 1 \\
\text { Delfi } 1 \\
\text { BNS, Delfi } 1 \\
\text { Elta } 2 \\
\text { Dainius Sinkevi- } \\
\text { čius } 1 \\
\text { Reuters } 1\end{array}$ & $\begin{array}{l}\text { Vitalijus Micha- } \\
\text { lovskis }\end{array}$ & $\begin{array}{l}15 \text { min } 15 \\
\text { Simas Čelutka } 1 \\
\text { BNS } 4 \\
\text { Paulius Gritènas } \\
3 \\
\text { Edwardas Luca- } \\
\text { sas } 1 \\
\text { Indrè Anskai- } \\
\text { tytė } 1 \\
\text { LRT } 1\end{array}$ \\
\hline
\end{tabular}

Atlikta straipsnių ir informacinių pranešimų kalbinė naratyvinė analizè: tirta, kokị prasminị lauką kuria tekstuose vartojami tiesiogiai su V. Putinu - jo veikla, psichologinèmis ir fizinèmis savybèmis, poelgiais ir sprendimais - susiję žodžiai ir žodžių junginiai, jų semantinès struktūros elementai, leksiniai ir sąvokiniai ryšiai, konotacinès savybės. Remiantis šių žodžių ir žodžių junginių semantika nustatomi bruožai ir savybės, formuojantys vieną arba kitą V. Putino naratyvą, kurị, tikètina, suvoks arba nesąmoningai / pusiau sąmoningai fiksuos teksto adresatai, t. y. portalo skaitytojai. V. Putino naratyvui darantys itaką žodžiai ir žodžių junginiai bei jų interpretacija pateikti lentelèse straipsnio Priede.

Išanalizuoti duomenys apibendrinti kiekybinèmis ir leksinemis charakteristikomis. Kiekybiškai dominuojantys naratyvai pateikti 1 ir 2 diagramose:

${ }^{23}$ Ieškant informacijos ir portale Lrytas.lt, ir „Google“ paieškoje, tinkinant laikotarpi, nepavyko rasti daugiau duomenų, nors gali būti, kad jie yra kitaip saugomi ir per paiešką neprieinami. Tačiau tyrimui, nustatant tendencijas, esminès įtakos galima paklaida neturi. 


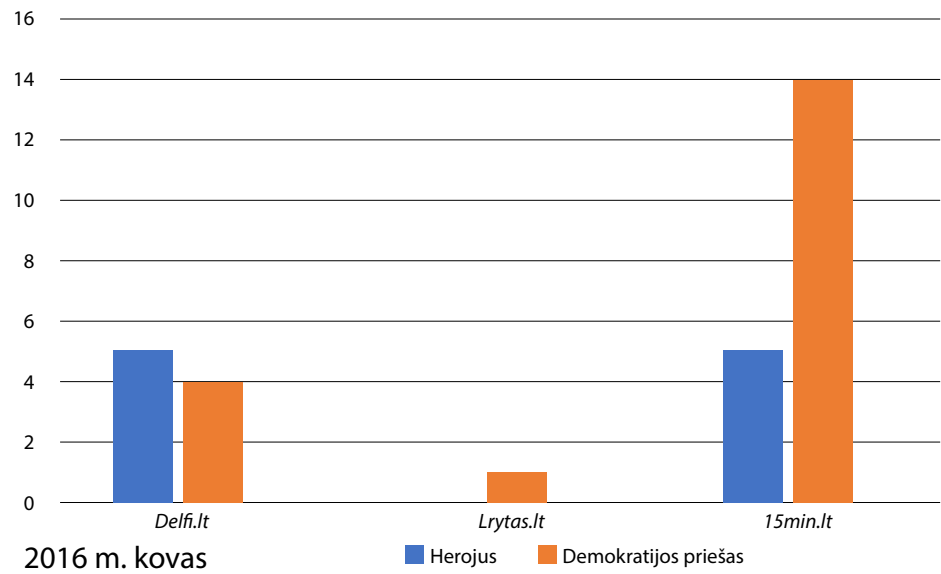

1 diagrama. Naratyvų Putinas - demokratijos priešas ir Putinas - herojus pasiskirstymas portalų publikacijose $2016 \mathrm{~m}$. kovo mènesị (remiantis Priede pateiktais duomenimis)

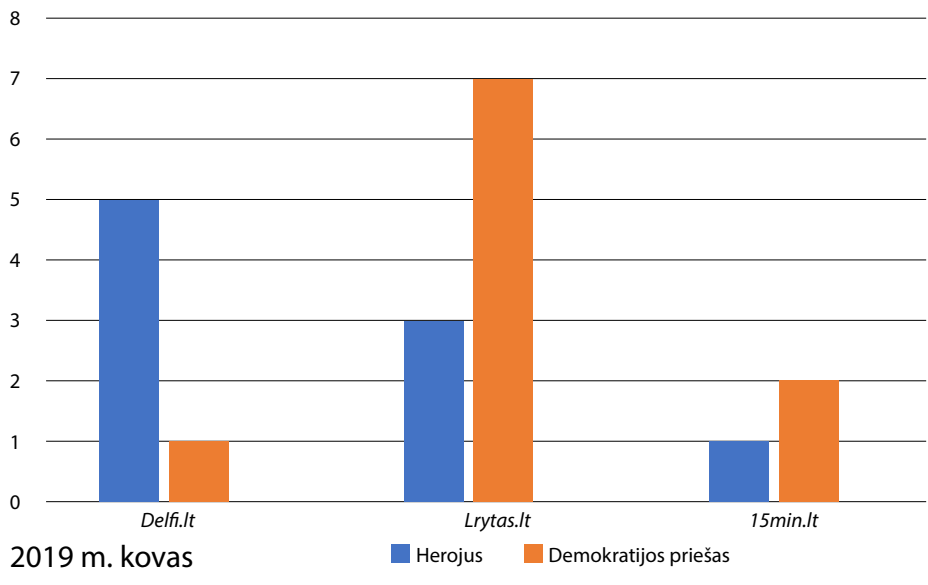

2 diagrama. Naratyvų Putinas - demokratijos priešas ir Putinas - herojus pasiskirstymas portalų publikacijose $2019 \mathrm{~m}$. kovo mènesị (remiantis Priede pateiktais duomenimis) 
Matome, kad lietuviškuose portaluose palaikomas ir svetimos ideologijos suformuotas naratyvas Putinas - herojus. Jo atsiradimo žiniasklaidoje priežastys - politologų sritis. Žiūrint iš lingvistinès perspektyvos, tikètina, kad naratyvo Putinas - herojus palaikymas kai kuriuose tekstuose galejo atsirasti dèl pirminio informacijos šaltinio įtakos tekstų vertimui. Kad skirtingas tos pačios informacijos vertimas skirtingos semantikos žodžiais kuria kitokių prasminių laukų, parodo pavyzdžiai 3 lentelèje:

\section{3 lentele. Tos pačios informacijos pateikimas skirtinguose portaluose}

\begin{tabular}{|c|c|}
\hline Delfi.lt & 15 min.lt \\
\hline $\begin{array}{l}\text { Pavadinimas: } \\
\text { Valstybés sekretoriu pamatęs } \\
\text { V. Putinas: sutrikau }\end{array}$ & $\begin{array}{l}\text { Pavadinimas: } \\
\text { Vladimiras Putinas pasišaipè iš Johno } \\
\text { Kerry atsigabento lagamino }\end{array}$ \\
\hline $\begin{array}{l}\text { Cituojamas V. Putinas } \\
\text { „Šiandien, kai pamačiau, kaip } \\
\text { lipate iš lèktuvo ir nešatės } \\
\text { daiktus, kiek sutrikau. Viena } \\
\text { vertus, tai labai demokratiška, } \\
\text { kita vertus, galvoju, turbūt } \\
\text { visai prasti reikalai JAV, nèra } \\
\text { kam padèti valstybės sekre- } \\
\text { toriui nešti lagaminą. Na bet } \\
\text { ekonomikoje, rodos, viskas ge- } \\
\text { rai, didelių sumažinimų nèra. } \\
\text { Paskui pagalvojau - gal tame } \\
\text { lagamine buvo tai, ko negalè- } \\
\text { jote niekam patikèti, kažkas } \\
\text { vertingo, gal pinigų atsivežète, } \\
\text { kad geriau sektųsi derètis } \\
\text { esminiais klausimais“, - sakè } \\
\text { V. Putinas. }\end{array}$ & $\begin{array}{l}\text { Cituojamas V. Putinas } \\
\text { „Šiandien, kai pamačiau, kaip lipate iš } \\
\text { lèktuvo ir nešate savo daiktus, šiek tiek } \\
\text { susikrimtau. Viena vertus, tai labai } \\
\text { demokratiška, bet kita vertus, pagalvojau: } \\
\text { JAV padėtis tikrai prasta, jeigu nebėra } \\
\text { kam padėti valstybės sekretoriui panešti } \\
\text { lagaminą“, - V. Putinas pajuokavo prieš } \\
\text { prasidedant jųdviejų deryboms Kremliuje, } \\
\text { per kurias J. Kerry stengèsi pakeisti Rusi- } \\
\text { jos lyderio poziciją dèl Sirijos prezidento } \\
\text { Basharo al Assado. } \\
\text { "Su (JAV) ekonomika lyg ir viskas gerai, } \\
\text { didelių darbuotojų atleidimų nevyksta, - } \\
\text { sarkastiškai tęsè V. Putinas, žvelgdamas ị } \\
\text { besišypsanti J. Kerry. - Po to pagalvojau: } \\
\text { galbūt tame lagamine buvo kažkas, ko ne- } \\
\text { galëjot niekam patikèti; kažkas vertinga. } \\
\text { Ko gera, pinigù atvežè, kad mums būtų } \\
\text { parankiau derètis dèl esminių klausimų.“ }\end{array}$ \\
\hline
\end{tabular}


V. Putino reakcijai nusakyti vartojami skirtingi žodžiai: sutrikau (prasminiu lygiu - tai nuoroda ị žmogišką reakciją, kiekvienas gali sutrikti) ir susikrimtau (prasminiu lygiu - tai ironiška reakcija, nes nuliūsti, jei aukštas pareigūnas pats neša lagaminą, galima tik ironiškai, pasišaipant. Šią ironišką veiksmažodžio nuliūsti konotaciją patvirtina kontekstas - V. Putinas kalba sarkastiškai). V. Putino vertinimą skirtingi žodžiai implikuoja skirtingai. Viename portale V. Putinas besišaipantis ir sarkastiškas (priešas), kitame - žmogiškas (herojus).

Iliustratyvūs ir žodžių debesys, kuriuose išryškinti tekstuose pasikartojantys žodžiai apie V. Putiną (remiantis Priede pateiktais duomenimis):

\begin{tabular}{|c|c|}
\hline $\begin{array}{c}\text { Žodžių debesis, formuojantis } \\
\text { naratyvą Putinas - herojus }\end{array}$ & $\begin{array}{c}\text { Žodžių debesis, formuojantis } \\
\text { naratyvą Putinas - priešas }\end{array}$ \\
\hline 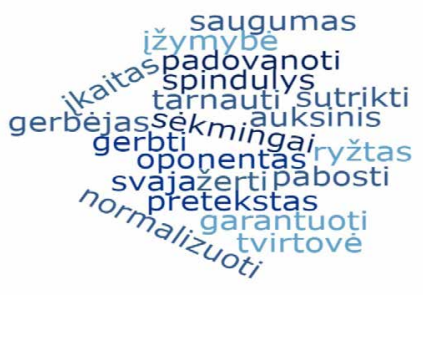 & 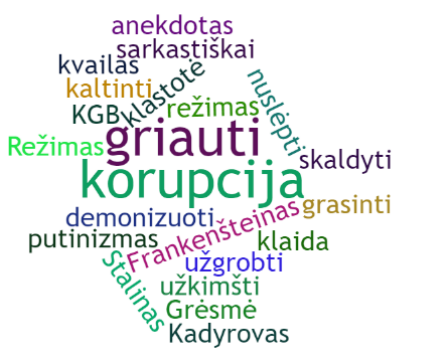 \\
\hline
\end{tabular}

2 paveikslas. Žodžių debesys, formuojantys naratyvą

Pirmuoju atveju matome, kad dominuoja stiprią teigiamą prasmę turintys žodžiai saugumas, spindulys, dominuoti, kurie kuria naratyvą Putinas - herojus. Antruoju atveju išryškejja neigiami žodžiai griauti, korupcija, jie kuria naratyvą Putinas - priešas.

3 paveiksle parodytos galimos ideologinès teksto suvokimo ir vertinimo implikacijos (remiantis Priede pateiktais duomenimis): 


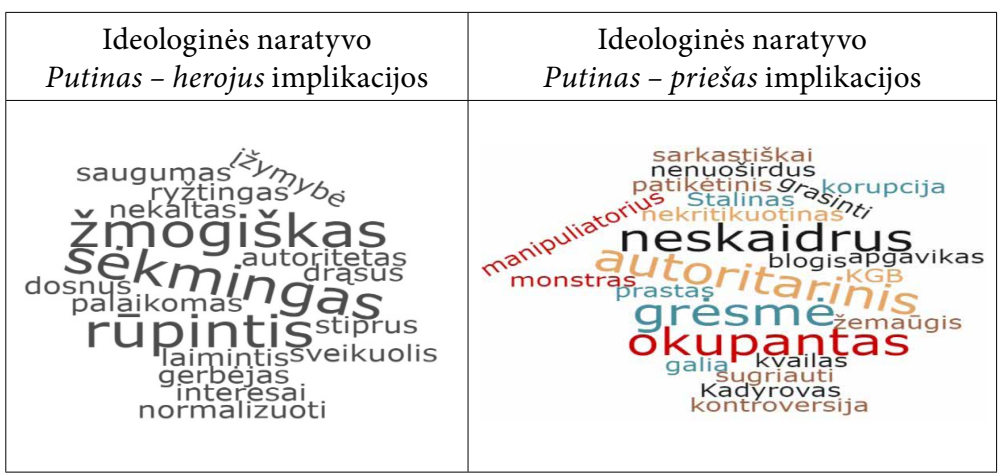

3 paveikslas. Ideologinès naratyvo implikacijos

Gali būti, kad ideologinès implikacijos sukuriamos nesąmoningai. Tačiau akivaizdu, kad virtualioje multimedijų aplinkoje yra palanki terpè joms atsirasti.

Ką tai reiškia kalbant apie hibridinius karus? Galima ir sąmoningai parinkti žodžius taip, kad būtų sukurtos ideologinès implikacijos. Tai hibridinių karų aplinkoje leistų žiniasklaidoje kariauti už politiniams ir geopolitiniams priešams palankų mąstymą, keisti vertybines nuostatas ir formuoti viešai nepageidaujamą nuomonę. Margaritos Dobryninos, tyrinejusios nusikaltimų baimès konstravimo žiniasklaidoje procesus, pastebejjimas iš esmès yra universalus: „žiniasklaidos nusikaltimų baimès diskursas bei naratyvai nèra savarankiški ir nepriklausomi, kadangi „nusikaltimų baimès“ ciklas apima daugybę socialinių veikèjų, sąlygojančių jų funkcionavimą. Todèl galima kalbėti apie tam tikrą egzistuojantị ryšị tarp žiniasklaidos ir nusikaltimų baimès, tačiau ne apie jų tiesioginị priežastinị santykį. ${ }^{\text {“24 }}$

${ }^{24}$ Dobrynina, M. Nusikaltimų baimès konstravimas žiniasklaidoje. Teisès problemos. Nr. 3(61). Vilnius, 2008, p. 83-111. 


\section{Išvados}

Tyrimo rezultatai iš esmès privedè prie svarbiausios šio straipsnio išvados, kad epochoje, kai virtualioje aplinkoje dominuoja naujosios medijos, kalba sustiprina savo poveikio galimybes. Atsiranda palanki ideologinių implikacijų terpè. Per žodžius sukuriamos ideologinès implikacijos gali formuoti nepageidaujamą ir (arba) priešišką naratyvą. Tai svarbu suvokti hibridinių karų epochoje. Politologai perspėja, kad:

„Rusijos konfrontacijos su Vakarais 2014-2016 m. laikotarpio vienas iš išskirtinių bruožų yra Rusijos propagandos suaktyvinimas tiek užsienyje, tiek pačioje Rusijoje. Lietuva, kurios santykių normalizacija su didžiąja kaimyne nebuvo užbaigta ir kuri atvirai parèmé Ukrainos poziciją, susilauke papildomo Rusijos žiniasklaidos dèmesio, o tiksliau, joje sustiprèjo antilietuviškų nuotaikų kurstymas. Šiuo atveju pirmiausia mėginama bendrais bruožais apibūdinti, kaip masinès informavimo priemonès (televizija ir periodinè spauda) atliko socialinio konstrukto kūrẻjų vaidmenį, ir išsiaiškinti Rusijos žiniasklaidoje pateikiamas Lietuvos kiekybines charakteristikas. Remiantis šia analize išskiriami trys dominuojantys negatyvūs Lietuvos ịvaizdžiai - rusofobiška ir antirusiška, istorijos falsifikuotoja, žlunganti ir neįtakinga. Šie ịvaizdžiai nuosekliai ir kryptingai eksploatuojami Rusijos informacinejje erdveje, beveik neegzistuojant alternatyviems šaltiniams, tapo neginčijama tiesa daugumai Rusijos piliečių. Tai suteikia Kremliui dideles manipuliacijos perspektyvas kuriant geopolitinio nestabilumo taktiką ir strategiją. " 25

Kas galètų paneigti, kad ir Lietuvos žiniasklaidą bandoma paveikti būtent per žodžiais kuriamas ideologines implikacijas. Negalime teigti, kad Lietuvoje esantys portalai turi tokio tipo geopolitinių užsakymų, tačiau neatkreipus dėmesio ị kalbos veikimo mechanizmus galima ir nežinant tapti priešiškų politinių jègų vykdytoju kritiškai neįvertinant

${ }^{25}$ Pugačiauskas, V. Lietuvos įvaizdžiai Rusijos žiniasklaidoje po Krymo aneksijos. Lietuvos metiné strateginé apžvalga. T. 15 (2016-2017), Vilnius, 2017, p. 113-129. 
konkrečių žodžių, semantinių konstrukcijų, žodžių junginių pasirinkimo, verčiant rusiškų ir prorusiškų naujienų agentūrų informaciją.

Tokio pobūdžio tyrimas yra pirmas, todèl jo išvadoms sutvirtinti reikètų eksperimentinio teksto suvokimo tyrimo, tačiau tai jau ateities dalykai.

Akivaizdu, kad greta tradicinių bendrojo raštingumo, stiliaus išmanymo reikalavimų privaloma išmokti semantinio raštingumo, kad kaip XIX amžiaus beraščiai valstiečiai nebūtume įstumti ị nepatogias, nepalankias ir net pavojingas situacijas.

\section{Literatūra}

1. Aleksaitè, A. Emocinè-ekspresinè leksika kaip kalbinè politikų portretų kūrimo priemonè naujienų portale Delfi.lt. Bendriné kalba. T. 89 [elektroninis išteklius]. Vilnius, 2016, 1 pdf, 15 p.

2. Baker, C. What Can Words Mean? Encyclopedia of Cognitive Science. Oxford: Macmillan Publishers, 2000.

3. Baranovskaja, I.; Skorupa, P. Some aspects of English idiom in traditional media classification and the problem of translation into Lithuanian. Santalka: filologija, edukologija. T. 21. Nr. 1. Vilnius, 2013, p. 5-12.

4. Čičirkaitè, R. Radijuj ir televizijoj gal net vilnietiškai jie kalba. Sakytinès žiniasklaidos ir Vilniaus kalbos nekirčiuotų kintamųjų /i:/, /u:/, /e:/, /o:/, /æ:/ ir /a:/ akustinè analizè. Taikomoji kalbotyra. T. 8 [elektroninis išteklius]. Vilnius, 2016, p. 107-135.

5. Dobrynina, M. Nusikaltimų baimès konstravimas žiniasklaidoje. Teises problemos. Nr. 3(61). Vilnius, 2008, p. 83-11.

6. Daya, S.; Lau, L. Power and narrative. Narrative Inquiry. Vol. 17. Amsterdam, Philadelphia, 2007, p. 1-13.

7. Dijk, van T. A. Ideology and discourse. A Multidisciplinary Introduction. Los Angeles, London, New Delph, Singapore, Washington DC: Sage, 2011, p. 44, p. 47.

8. Dijk, van T. A. Narrative macro-structures. Logical and Cognitive Foundations. A Journal for Descriptive Poetics and Theory of Literature. Vol. 1 (1976), p. 547-568. 
9. Karaliūnas, S. Kalba ir visuomenè. Psichologiniai ir komunikaciniai kalbos vartojimo bruožai. Vilnius, 1997, p. 132-136.

10. Kensminienè, A. Mịslių suvokimo raida: nuo refleksijos tradicinèse mịslèse iki termino metaforinio išskydimo masinèse žiniasklaidos priemonèse. Tautosakos darbai. T. 54, 2017, p. 26-48.

11. Koženiauskienė, R. Perkurtos frazeologijos žaismas žiniasklaidoje. Kalbos kultūra. Nr. 86. Vilnius, 2013, p. 149-166.

12. Liepinytè-Kytrienė, D. Antraščių-faktinių teiginių poveikio priemonės interneto portale Delfi.lt. Taikomoji kalbotyra. T. 2 [elektroninis išteklius]. Vilnius, 2013, $1 \mathrm{html}$.

13. Mažylè, J. Naujienų atrankos ịtaka publikacijos pateikimo būdui ir formai. Medijos, žiniasklaida, žurnalistika tradicinejje ir tinklaveikos visuomeneje. Kolektyvinè monografija, red. Ž. Pečiulis, Vilnius, 2012, p. 165-171.

14. McLuhan, M. Kaip suprasti medijas. Vilnius, 2003, p. 91.

15. Ophir, E.; Nass, C.; Wagner, A. D. Cognitive control in media multitaskers. Proceedings of the National Academy of Sciences of the United States of America. 2009.

16. Prince, G. Apie šiuolaikinę naratologiją. Žmogus ir žodis. T. 16, Nr. 2. Vilnius, 2014, p. 106-10.

17. Pugačiauskas, V. Lietuvos ịvaizdžiai Rusijos žiniasklaidoje po Krymo aneksijos. Lietuvos metine strateginė apžvalga. T. 15 (2016-2017). Vilnius, 2017, p. 113-129.

18. Senvaitytė, D.; Gražytė, R. Senąją lietuvių religiją nusakanti terminija bei jos kontekstas elektroninèje Lietuvos žiniasklaidoje. Žmogus kalbos erdveje. Nr. 6. Kaunas, 2010, p. 479-488.

19. Smetonienè, I. Žiniasklaidos kalba ir stilius: tartis ir kirčiavimas [elektroninis išteklius]. 2014-d., 1 pdf, 48 p.

20. Underhill, J. Humboldt, Worldview and Language. Edinburgh: Edinburgh University Press, 2009.

21.Whorf, B. L.; Carroll, J. B. Language, Thought, and Reality. Selected Writings of Benjamin Lee Whorf. Massachusetts: MIT Press, 1964. 


\section{PRIEDAS}

\section{1. lentelé. Ideologinès V. Putino naratyvo implikacijos}

\begin{tabular}{|c|c|c|}
\hline $\begin{array}{l}\text { Straipsnio / informacijos / } \\
\text { pranešimo šaltinis, pavadini- } \\
\text { mas, internetinė nuoroda ir } \\
\text { paskelbimo data }\end{array}$ & Citata & $\begin{array}{l}\text { Ideologinės V. Putino } \\
\text { naratyvo implikacijos }\end{array}$ \\
\hline I. www.delfi.lt & www.delfi.lt & www.delfi.lt \\
\hline $\begin{array}{l}\text { Rima Janužytė, žurnalas } \\
\text { „Veidas“. } \\
\text { V. Putino kvietimas labiau } \\
\text { šiurpina nei džiugina } \\
\text { https://www.delfi.lt/news/ } \\
\text { daily/lithuania/v-putino-kvie- } \\
\text { timas-labiau-siurpina-nei- } \\
\text { dziugina.d?id=70482014 } \\
2016 \mathrm{~m} . \text { kovo } 3 \mathrm{~d} .\end{array}$ & $\begin{array}{l}\text { Apie šią V. Putino } \\
\text { šypseną, kaip ir apie } \\
\text { susitikimą su Euro- } \\
\text { pos žydų kongreso } \\
\text { nariais bei jo metu } \\
\text { nuskambejusį kvieti- } \\
\text { mą visiems Europos } \\
\text { žydams keltis gyventi } \\
\text { ì Rusiją, jau sklando } \\
\text { anekdotai. }\end{array}$ & $\begin{array}{l}\text { Nenuoširdus. } \\
\text { Sklando anekdotai - pa- } \\
\text { nieką reiškiantis žodžių } \\
\text { junginys. } \\
\text { Apie šypsena sklando } \\
\text { anekdotai, vadinasi, žodis } \\
\text { šypsena, kuri savaime yra } \\
\text { teigiamo reiškinio pavadi- } \\
\text { nimas, } \\
\text { tgauna enantioseminę } \\
\text { referenciją. }\end{array}$ \\
\hline $\begin{array}{l}\text { Olegas Jerofejevas, Delfi.lt. } \\
\text { J. Kiseliovas: aš irgi pažiūrejjau } \\
\text { V. Putinui i̇ akis ir pamačiau } \\
\text { tik KGB pulkininką } \\
\text { https://www.delfi.lt/news/ } \\
\text { daily/lithuania/j-kiseliovas- } \\
\text { as-irgi-paziurejau-v-putinui- } \\
\text { i-akis-ir-pamaciau-tik-kgb- } \\
\text { pulkininka.d?id=70700902 } \\
2016 \text { m. kovo } 15 \mathrm{~d} .\end{array}$ & $\begin{array}{l}\text { Jis taip pat kalbejo } \\
\text { apie Vakarus sargdi- } \\
\text { nantị tikrų lyderių } \\
\text { stygių, dèl kurio jie } \\
\text { prarado gerą formą, } \\
\text { ir būtinybę priešintis } \\
\text { Rusijos prezidento } \\
\text { Vladimiro Putino } \\
\text { režimo keliamai } \\
\text { grèsmei. }\end{array}$ & $\begin{array}{l}\text { Valdymas kelia grèsmę. } \\
\text { Režimas - stiprios konota- } \\
\text { cijos žodis, kuris nurodo, } \\
\text { kad valdymo būdas yra } \\
\text { nepriimtinas. } \\
\text { Grésmè - pragmatiniu } \\
\text { požiūriu labai neigiamos } \\
\text { tiesioginès reikšmės žodis. }\end{array}$ \\
\hline
\end{tabular}




\begin{tabular}{|c|c|c|}
\hline $\begin{array}{l}\text { Straipsnio / informacijos / } \\
\text { pranešimo šaltinis, pavadini- } \\
\text { mas, internetinè nuoroda ir } \\
\text { paskelbimo data }\end{array}$ & Citata & $\begin{array}{l}\text { Ideologinės V. Putino } \\
\text { naratyvo implikacijos }\end{array}$ \\
\hline $\begin{array}{l}\text { Lrt.lt. } \\
\text { V. Putino svajose ir vėl Jalta } \\
\text { https://www.delfi.lt/news/ } \\
\text { daily/world/v-putino-svajose- } \\
\text { ir-vel-jalta.d?id=70761594 } \\
2016 \text { m. kovo } 22 \mathrm{~d} .\end{array}$ & $\begin{array}{l}\text { Vladimiro Putino } \\
\text { ryžtas ir agresyvi } \\
\text { veikla užsienyje lemia } \\
\text { dideli visuomenės } \\
\text { palaikymą Rusijoje. } \\
\text { Tačiau šiuos V. Putino } \\
\text { pasiekimus lenkia dar } \\
\text { vienas - svarbiau- } \\
\text { sias - laimėjimas. } \\
\text { Pirmosios dvi V. Pu- } \\
\text { tino prezidentavimo } \\
\text { kadencijos (2000- } \\
\text { 2008) pasižymejo } \\
\text { politine stabilizacija ir } \\
\text { ekonominiu augimu. }\end{array}$ & $\begin{array}{l}\text { Ryžtingas, palaikomas, } \\
\text { sėkmingas ir laimintis. } \\
\text { Su V. Putino veikla siejami } \\
\text { teigiamos reikšmės žodžiai } \\
\text { ir kolokacijos: ryžtas, palai- } \\
\text { kymas, pasiekimas, laimé- } \\
\text { jimas, politine stabilizacija, } \\
\text { ekonominis augimas. } \\
\text { Pavadinime esantis žodis } \\
\text { svaja, neutralesnio žodžio } \\
\text { svajoné sinonimas, priklauso } \\
\text { vadinamajam poetiniam } \\
\text { stiliui, todèl šio žodžio var- } \\
\text { tojimas yra aktualizuotas, su } \\
\text { nuoroda ị intymumą, santy- } \\
\text { kio su informacijos subjektu } \\
\text { V. Putinu suasmeninimą. }\end{array}$ \\
\hline $\begin{array}{l}\text { Eglè Samoškaitè. } \\
\text { Juodosios Rusijos šaknys - } \\
\text { V. Putinas čia ịkaitas } \\
\text { https://www.delfi.lt/news/ } \\
\text { daily/lithuania/juodosios-rusi- } \\
\text { jos-saknys-v-putinas-cia-yra- } \\
\text { ikaitas.d?id=70669744 } \\
2016 \mathrm{~m} . \text { kovo } 15 \mathrm{~d} .\end{array}$ & $\begin{array}{l}\text { Ji sako, kad būtų } \\
\text { klaidinga manyti, jog } \\
\text { V. Putinas pats viską } \\
\text { valdo, iš tikrųjų jis yra } \\
\text { sistemos ịkaitas. } \\
\text { Pagrindinis šios struk- } \\
\text { tūros bruožas - galios } \\
\text { centro nebuvimas, } \\
\text { todèl šiuo atveju V. Pu- } \\
\text { tinas irgi nelaikomas } \\
\text { galios centru, jis yra } \\
\text { sistemos įkaitas, kuris } \\
\text { užsiima daugiau mikro } \\
\text { lygmens sprendimais. }\end{array}$ & $\begin{array}{l}\text { Neatsako už Rusijos politi- } \\
\text { ką (nekaltas). } \\
\text { Žodis įkaitas semantiškai } \\
\text { susijęs su aukos semantika. }\end{array}$ \\
\hline $\begin{array}{l}\text { Delfi.lt. } \\
\text { „Forbes“: strategine V. Putino } \\
\text { klaida } \\
\text { https://www.delfi.lt/news/dai- } \\
\text { ly/world/forbes-strategine-v- } \\
\text { putino-klaida.d?id=70635580 } \\
2016 \text { m. kovo } 9 \text { d. }\end{array}$ & $\begin{array}{l}\text { Rusijos prezidentas } \\
\text { nuolat ignoruoja tarp- } \\
\text { tautinės teisės normas. } \\
\text { Nepaisant to, jeigu } \\
\text { V. Putinas pabėgèlius } \\
\text { iš Sirijos iš tikrujų } \\
\text { naudoja kaip savotišką } \\
\text { ginklą prieš Europą, jis } \\
\text { daro strateginę klaidą. }\end{array}$ & $\begin{array}{l}\text { Prastas strategas. } \\
\text { Strateginé klaida-stiprios } \\
\text { neigiamos reikšmės kolo- } \\
\text { kacija. }\end{array}$ \\
\hline
\end{tabular}




\begin{tabular}{|c|c|c|}
\hline $\begin{array}{l}\text { Straipsnio / informacijos / } \\
\text { pranešimo šaltinis, pavadini- } \\
\text { mas, internetinė nuoroda ir } \\
\text { paskelbimo data }\end{array}$ & Citata & $\begin{array}{l}\text { Ideologinès V. Putino } \\
\text { naratyvo implikacijos }\end{array}$ \\
\hline $\begin{array}{l}\text { BNS, Delfi.lt. } \\
\text { JAV valstybès sekretoriu pa- } \\
\text { matęs V. Putinas: sutrikau } \\
\text { https://www.delfi.lt/news/ } \\
\text { daily/world/jav-valstybes-se- } \\
\text { kretoriu-pamates-v-putinas- } \\
\text { sutrikau.d?id=70800780 } \\
2016 \mathrm{~m} . \text { kovo } 25 \mathrm{~d} .\end{array}$ & $\begin{array}{l}\text { „Šiandien, kai } \\
\text { pamačiau, kaip lipate } \\
\text { iš lèktuvo ir nešatès } \\
\text { daiktus, kiek sutri- } \\
\text { kau." }\end{array}$ & $\begin{array}{l}\text { Žmogiškai gali sutrikti. } \\
\text { Sutrikti - žmogiško jausmo } \\
\text { ị(si)vardijimas. } \\
\text { Ši V. Putino citata portale } \\
\text { 15min.lt pateikta su kitos } \\
\text { semantikos žodžiu susi- } \\
\text { krimtau (vietoj sutrikau). }\end{array}$ \\
\hline $\begin{array}{l}\text { Elta. } \\
\text { „Pussy Riot“ narė - V. Putinas } \\
\text { sugriovė daugybės žmonių } \\
\text { svajones } \\
\text { https://www.delfi.lt/ } \\
\underline{\text { news/daily/world/ }} \\
\frac{\text { pussy-riot-nare-v-puti- }}{\text { nas-sugriove-daugybes-zmo- }} \\
\underline{\text { niu-svajones.d?id=70683222 }} \\
2016 \text { m. kovo } 14 \mathrm{~d} .\end{array}$ & $\begin{array}{l}\text { „Dar ne viskas } \\
\text { prarasta“, - pabrèžè } \\
\text { ji, akcentuodama, kad } \\
\text { V. Putinas sugriovė } \\
\text { daugybės žmonių } \\
\text { svajones. }\end{array}$ & $\begin{array}{l}\text { Blogio nešèjas. } \\
\text { Sugriauti žmoniu svajo- } \\
\text { nes- neigiamos konotacijos } \\
\text { frazeologizmas, lingvistinès } \\
\text { pragmatikos požiūriu } \\
\text { turintis stiprų suasmenintą } \\
\text { poveikị. }\end{array}$ \\
\hline $\begin{array}{l}\text { Dainius Sinkevičius. } \\
\text { Kaunietį nuteisè už } 15 \text { komen- } \\
\text { tarų: tyčiojosi iš V. Putino ir } \\
\text { Rusijos } \\
\text { https://www.delfi.lt/news/ } \\
\text { daily/law/kaunieti-nutei- } \\
\text { se-uz-15-komentaru-tycio- } \\
\text { josi-is-v-putino-ir-rusijos- } \\
\text { zmoniu.d?id=70782764 } \\
2016 \text { m. kovo } 23 \mathrm{~d} \text {. }\end{array}$ & $\begin{array}{l}\text { Rusijos valstybė, jos } \\
\text { prezidentas Vladi- } \\
\text { miras Putinas <...> } \\
\text { buvo tapę pagrindiniu } \\
\text { A. Gaudžiūno taiki- } \\
\text { niu - viešoje erdvèje } \\
\text { rašydamas komen- } \\
\text { tarus vyras juos ne } \\
\text { tik niekino, skatino } \\
\text { neapykantą, bet ir } \\
\text { kurstè diskriminuoti, } \\
\text { smurtauti bei fiziškai } \\
\text { susidoroti. }\end{array}$ & $\begin{array}{l}\text { Nekritikuotinas. } \\
\text { Tekstas apie neapykantos } \\
\text { kurstymą internete sukons- } \\
\text { truotas taip, kad ji galima } \\
\text { suprasti kaip perspejjimą } \\
\text { nekritikuoti V. Putino. }\end{array}$ \\
\hline
\end{tabular}




\begin{tabular}{|c|c|c|}
\hline $\begin{array}{l}\text { Straipsnio / informacijos / } \\
\text { pranešimo šaltinis, pavadini- } \\
\text { mas, internetinė nuoroda ir } \\
\text { paskelbimo data }\end{array}$ & Citata & $\begin{array}{l}\text { Ideologinės V. Putino } \\
\text { naratyvo implikacijos }\end{array}$ \\
\hline $\begin{array}{l}\text { Reuters. } \\
\text { Interneto sensacija virtusi } \\
\text { V. Putino parodija } \\
\text { https://www.delfi.lt/video/ } \\
\text { aktualijos/interneto-sen- } \\
\text { sacija-virtusi-vputino- } \\
\text { parodija.d?id=70635714 } \\
2016 \mathrm{~m} . \text { kovo } 14 \mathrm{~d} .\end{array}$ & $\begin{array}{l}\text { Per dvi savaites in- } \\
\text { ternetineje svetainèje } \\
\text { „Youtube“ paskelbta } \\
\text { slovėnų aktoriaus } \\
\text { ir komiko Klemeno } \\
\text { Slakonjos sukurta } \\
\text { Rusijos prezidento } \\
\text { Vladimiro Putino } \\
\text { parodija surinko } \\
\text { daugiau gerbejjų nei } \\
\text { K. Slakonjos tèvynejje } \\
\text { gyvena žmonių. }\end{array}$ & $\begin{array}{l}\text { Turi gerbèju } \\
\text { Gerbèjas - teigiamos } \\
\text { reikšmès žodis, itin aktua- } \\
\text { lizuotas medijų (socialinių } \\
\text { tinklų) diskurse, dèl šio } \\
\text { diskurso ypatumų jo teigia- } \\
\text { mo pragmatinio poveikio } \\
\text { nesumažina tai, kad gerbèjai } \\
\text { domisi parodija. } \\
\text { Tekste pavartotas ir } \\
\text { vaizdingas palyginimas - } \\
\text { gerbèjų daugiau nei žmonių } \\
\text { Slovėnijoje. Tai tiesioginè } \\
\text { nuoroda, kad V. Putinas yra } \\
\text { labai populiarus. }\end{array}$ \\
\hline $\begin{array}{l}\text { Elta. } \\
\text { B. Obama ir V. Putinas } \\
\text { telefonu aptarė Rusijos pajėgu } \\
\text { išvedimą iš Sirijos } \\
\text { https://www.delfi.lt/news/ } \\
\text { daily/world/b-obama-ir- } \\
\text { v-putinas-telefonu-aptare- } \\
\text { rusijos-pajegu-isvedima-is- } \\
\text { sirijos.d?id=70691212 } \\
2016 \mathrm{~m} . \text { kovo } 15 \mathrm{~d} .\end{array}$ & & $\begin{array}{l}\text { V. Putino vertinimo atžvil- } \\
\text { giu informacija nekono- } \\
\text { tuota. }\end{array}$ \\
\hline II. www.lrytas.lt & www.lrytas.lt & www.lrytas.lt \\
\hline $\begin{array}{l}\text { Vitalijus Michalovskis. } \\
\text { Miręs J. Stalinas rusams - } \\
\text { toks pats mielas kaip gyvas } \\
\text { V. Putinas } \\
\text { https://kultura.lrytas.lt/ } \\
\text { istorija/2016/03/05/news/ } \\
\text { mires-j-stalinas-rusams-toks- } \\
\text { pat-mielas-kaip-gyvas-v-puti- } \\
\text { nas-834857/ } \\
2016 \text { m. kovo } 5 \mathrm{~d} .\end{array}$ & $\begin{array}{l}\text { Miręs J. Stalinas } \\
\text { rusams - toks pats } \\
\text { mielas kaip gyvas } \\
\text { V. Putinas. }\end{array}$ & $\begin{array}{l}\text { Putinas panašus ị Staliną. } \\
\text { Antrašte sukonstruota } \\
\text { kaip V. Putino ir J. Stalino } \\
\text { sugretinimas, o tai, žinoma, } \\
\text { labai neigiamos konotacijos } \\
\text { semantinis ir prasminis } \\
\text { efektas. }\end{array}$ \\
\hline
\end{tabular}




\begin{tabular}{|c|c|c|}
\hline $\begin{array}{l}\text { Straipsnio / informacijos / } \\
\text { pranešimo šaltinis, pavadini- } \\
\text { mas, internetinè nuoroda ir } \\
\text { paskelbimo data }\end{array}$ & Citata & $\begin{array}{l}\text { Ideologinès V. Putino } \\
\text { naratyvo implikacijos }\end{array}$ \\
\hline III. www.15min.lt & www. $15 \mathrm{~min} .1 \mathrm{t}$ & www.15min.lt \\
\hline $\begin{array}{l}\text { 15min.lt. } \\
\text { Nutekinti naujausi Vladimiro } \\
\text { Putino limuzino eskizai } \\
\text { https://www.15min.lt/gazas/ } \\
\text { naujiena/autorinka/nutekinti- } \\
\text { naujausi-vladimiro-putino-li- } \\
\text { muzino-eskizai-220-599175 } \\
2016 \mathrm{~m} . \text { kovo } 21 \mathrm{~d} .\end{array}$ & $\begin{array}{l}\text { Prieš tai tiek Dmi- } \\
\text { trijus Medvedevas, } \\
\text { tiek V. Putinas yra } \\
\text { pareiškę, kad pabodo } \\
\text { važinėti užsienie- } \\
\text { tiškais limuzinais } \\
\text { (šiuo metu Rusijos } \\
\text { prezidentą vežioja } \\
\text { „Mercedes“). }\end{array}$ & $\begin{array}{l}\text { Žmogiškai jaučia nuobo- } \\
\text { dulį. } \\
\text { Pabosti-buitinio stiliaus } \\
\text { veiksmažodis, suponuo- } \\
\text { jantis pranešimo subjekto } \\
\text { V. Putino žmogiškas savy- } \\
\text { bes, o tai visada teigiamai } \\
\text { suasmenina santyki su } \\
\text { subjektu. }\end{array}$ \\
\hline $\begin{array}{l}\text { Simas Čelutka. } \\
\text { Milijonus žmonių pražudęs } \\
\text { Josifas Stalinas - Vladimiro } \\
\text { Putino Rusijos herojus } \\
\text { https://www.15min.lt/ } \\
\text { naujiena/aktualu/istorija/stali- } \\
\text { no-smekla-vis-dar-klaidzioja- } \\
\text { rusijoje-582-598187?copied } \\
2016 \text { m. kovo } 20 \mathrm{~d} .\end{array}$ & $\begin{array}{l}\text { Labai panašiai ideolo- } \\
\text { gijos naudą supranta } \\
\text { KGB papulkininkis } \\
\text { Vladimiras Putinas } \\
<\ldots . \text { >. } \\
\text { Kaip Stalino laikais } \\
\text { komunistinio in- } \\
\text { ternacionalo idealą } \\
\text { pakeitè imperinis, } \\
\text { didžiavalstybinis } \\
\text { nacionalizmas, taip } \\
\text { ir šiandien regime } \\
\text { akivaizdžią tąsą tarp } \\
\text { sovietinių sentimentų } \\
\text { ir putininio „Krym- } \\
\text { naš“ šovinizmo. }\end{array}$ & $\begin{array}{l}\text { KGB bendradarbis. } \\
\text { KGB - lietuviškame kon- } \\
\text { tekste itin stiprios neigia- } \\
\text { mos konotacijos sąvoka. } \\
\text { Putininis (šovinizmas) - } \\
\text { naujažodis, turintis domi- } \\
\text { nuojančio naratyvo Puti- } \\
\text { nas - demokratijos priešas } \\
\text { semantinị elementą. }\end{array}$ \\
\hline $\begin{array}{l}\text { BNS. } \\
\text { Garis Kasparovas: Vladimiro } \\
\text { Putino tikslas - Europos } \\
\text { griūtis } \\
\text { https://www.15min.lt/ } \\
\text { naujiena/aktualu/interviu/ } \\
\text { garis-kasparovas-vladimiro- } \\
\text { putino-tikslas-europos-griu- } \\
\text { tis-599-593995 } \\
2016 \text { m. kovo } 10 \text { d. }\end{array}$ & $\begin{array}{l}\text { Putinas neslepia, kad } \\
\text { pagrindinis jo tiks- } \\
\text { las - Europos griūtis. }\end{array}$ & $\begin{array}{l}\text { Nori sugriauti Europą. } \\
\text { Griūtis - pragmatiniu } \\
\text { požiūriu labai neigiamos } \\
\text { tiesioginès reikšmès žodis, } \\
\text { plg. grèsme. }\end{array}$ \\
\hline
\end{tabular}




\begin{tabular}{|c|c|c|}
\hline $\begin{array}{l}\text { Straipsnio / informacijos / } \\
\text { pranešimo šaltinis, pavadini- } \\
\text { mas, internetinė nuoroda ir } \\
\text { paskelbimo data }\end{array}$ & Citata & $\begin{array}{l}\text { Ideologinès V. Putino } \\
\text { naratyvo implikacijos }\end{array}$ \\
\hline $\begin{array}{l}\text { 15min.lt. } \\
\text { Vladimiras Putinas rusų } \\
\text { verslininkams: neparduokite } \\
\text { Ukrainoje turimo turto } \\
\text { https://www.15min.lt/ } \\
\text { verslas/naujiena/bendroves/ } \\
\text { vladimiras-putinas-rusu- } \\
\text { verslininkams-neparduoki- } \\
\text { te-ukrainoje-turimo-turto- } \\
663-601441 \text { ?copied } \\
2016 \text { m. kovo } 28 \mathrm{~d} .\end{array}$ & $\begin{array}{l}\text { V. Putinas rekomen- } \\
\text { davo palaukti tikintis, } \\
\text { kad santykiai tarp } \\
\text { dviejų šalių normali- } \\
\text { zuosis. }\end{array}$ & $\begin{array}{l}\text { Tikisi normalizuoti san- } \\
\text { tykius. } \\
\text { Normalizuoti(s) - politinè } \\
\text { ir diplomatinè teigiamos } \\
\text { konotacijos sąvoka. }\end{array}$ \\
\hline $\begin{array}{l}\text { Paulius Gritėnas. } \\
\text { Rusijos opozicija aptare gyve- } \\
\text { nimą po Putino: „Reikès šalies } \\
\text { dekriminalizacijos“ } \\
\text { https://www.15min.lt/ } \\
\text { naujiena/aktualu/pasaulis/ } \\
\underline{\text { rusijos-opozicija-aptare-gy- }} \\
\text { venima-po-putino-reikes- } \\
\text { rusijos-dekriminalizacijos- } \\
\text { 2016 } 594165 \text { ? comments\&copied } \\
\end{array}$ & $\begin{array}{l}\text { Net ir Vakarų Europa } \\
\text { jau ima patikèti, kad } \\
\text { Putinas nori skaldyti } \\
\text { ES. }\end{array}$ & $\begin{array}{l}\text { Grèsmė Europai. } \\
\text { Skaldyti - perkeltine prasme } \\
\text { vartojamas veiksmažodis su } \\
\text { kultūrine nuoroda ị autori- } \\
\text { tarinės galios sąvokinį lauką } \\
\text { skaldyk ir valdyk. Neigiama } \\
\text { kolokacija su grèsmès pras- } \\
\text { miniu elementu. }\end{array}$ \\
\hline $\begin{array}{l}\text { Paulius Gritenas. } \\
\text { Politologas N. Maliukevičius } \\
\text { apie V. Putino taktiką: „Konf- } \\
\text { liktų eksportas tęsis“ } \\
\text { https://www.15min.lt/ } \\
\underline{\text { naujiena/aktualu/pasaulis/ }} \\
\underline{\text { nerijus-maliukevicius-iverti- }} \\
\underline{\text { no-vladimiro-putino-taktika- }} \\
\underline{\text { konfliktu-eksportas-tesis- }} \\
\underline{57-596305 \text { ?copied }} \\
2016 \text { m. kovo } 15 \mathrm{~d} .\end{array}$ & $\begin{array}{l}\text { Putinas, kaip sakè } \\
\text { Barackas Obama, } \\
\text { nėra visiškai kvailas, } \\
\text { kad nepaskaičiuotų } \\
\text { tokio karinio žingsnio } \\
\text { kaštų. }\end{array}$ & $\begin{array}{l}\text { Kvailas, nors nevisiškai. } \\
\text { Kvailas - pejoratyvas. }\end{array}$ \\
\hline
\end{tabular}




\begin{tabular}{|c|c|c|}
\hline $\begin{array}{l}\text { Straipsnio / informacijos / } \\
\text { pranešimo šaltinis, pavadini- } \\
\text { mas, internetinė nuoroda ir } \\
\text { paskelbimo data }\end{array}$ & Citata & $\begin{array}{l}\text { Ideologinės V. Putino } \\
\text { naratyvo implikacijos }\end{array}$ \\
\hline $\begin{array}{l}\text { BNS. } \\
\text { Vladimiras Putinas apsilankys } \\
\text { aneksuotame Kryme } \\
\text { https://www.15min.lt/ } \\
\text { naujiena/aktualu/pasaulis/ } \\
\text { vladimiras-putinas-apsi- } \\
\text { lankys-aneksuotame-kry- } \\
\text { me-57-598087 } \\
2016 \mathrm{~m} . \text { kovo } 18 \mathrm{~d} .\end{array}$ & & $\begin{array}{l}\text { V. Putino vertinimo atžvil- } \\
\text { giu informacija nekono- } \\
\text { tuota. }\end{array}$ \\
\hline $\begin{array}{l}\text { 15min.lt. } \\
\text { Vladimiras Putinas paskyrė } \\
\text { Ramzaną Kadyrovą laikinai } \\
\text { pareigas einančiu Čečènijos } \\
\text { vadovu } \\
\text { https://www.15min. } \\
\text { lt/naujiena/aktualu/ } \\
\text { pasaulis/vladimiras-pu- } \\
\text { tinas-paskyre-ramzana-ka- } \\
\text { dyrova-laikinai-pareigas- } \\
\text { einanciu-cecenijos-vadovu- } \\
57-601429 \text { ?comments\&copied } \\
2016 \text { m. kovo } 25 \text { d. }\end{array}$ & & $\begin{array}{l}\text { V. Putino vertinimo atžvil- } \\
\text { giu informacija nekono- } \\
\text { tuota. }\end{array}$ \\
\hline $\begin{array}{l}\text { 15min.lt. } \\
\text { Keistas Kremliaus žingsnis: } \\
\text { prabilo apie artimiausios Vla- } \\
\text { dimiro Putino aplinkos turtų } \\
\text { medžioklę } \\
\text { https://www.15min.lt/ } \\
\text { naujiena/aktualu/pasaulis/ } \\
\text { keistas-kremliaus-zingsnis- } \\
\text { prabilo-apie-artimiausios-vla- } \\
\text { dimiro-putino-aplinkos-turtu- } \\
\text { medziokle-57-602589?copied } \\
2016 \text { m. kovo } 29 \mathrm{~d} \text {. }\end{array}$ & $\begin{array}{l}\text { D. Peskovas nepralei- } \\
\text { do progos pagrasinti } \\
\text { V. Putino aplinka } \\
\text { besidomintiems žur- } \\
\text { nalistams. }\end{array}$ & $\begin{array}{l}\text { Grasina. } \\
\text { Grasinti - šio veiksmažo- } \\
\text { džio semantikoje yra pavo- } \\
\text { jaus sema (leksinès reikšmès } \\
\text { elementas), pragmatiniu ir } \\
\text { retoriniu požiūriu tai ypač } \\
\text { neigiamai priimamas žodis. }\end{array}$ \\
\hline
\end{tabular}




\begin{tabular}{|c|c|c|}
\hline $\begin{array}{l}\text { Straipsnio / informacijos / } \\
\text { pranešimo šaltinis, pavadini- } \\
\text { mas, internetinè nuoroda ir } \\
\text { paskelbimo data }\end{array}$ & Citata & $\begin{array}{l}\text { Ideologinès V. Putino } \\
\text { naratyvo implikacijos }\end{array}$ \\
\hline $\begin{array}{l}\text { BNS. } \\
\text { Vladimiras Putinas pasišaipe } \\
\text { iš Johno Kerry atsigabento } \\
\text { lagamino } \\
\text { https://www.15min.lt/ } \\
\text { naujiena/aktualu/pasaulis/ } \\
\text { vladimiras-putinas-pasisaipe- } \\
\text { is-johno-kerry-atsigabento-la- } \\
\text { gamino-57-601165?copied } \\
2016 \mathrm{~m} \text {. kovo } 25 \mathrm{~d} \text {. }\end{array}$ & $\begin{array}{l}\text { „Šiandien, kai } \\
\text { pamačiau, kaip lipate } \\
\text { iš lèktuvo ir nešate } \\
\text { savo daiktus, šiek tiek } \\
\text { susikrimtau. <...> Su } \\
\text { (JAV) ekonomika lyg } \\
\text { ir viskas gerai, didelių } \\
\text { darbuotojų atleidimų } \\
\text { nevyksta“, - sarkas- } \\
\text { tiškai tęsè V. Putinas, } \\
\text { žvelgdamas ị besišyp- } \\
\text { santị J. Kerry. }\end{array}$ & $\begin{array}{l}\text { Sarkastiškas JAV atžvilgiu. } \\
\text { Sarkastiškai - stiprios } \\
\text { neigiamos reikšmės, kono- } \\
\text { tuotas prieveiksmis. } \\
\text { V. Putino pasakyti žodžiai } \\
\text { pateikiami kitaip nei Delfi.lt } \\
\text { portale, kuriame V. Putinas } \\
\text { žmogiškai sutrikęs, o } \\
\text { 15min.lt publikacijoje jis } \\
\text { susikrimtęs, bet sarkas- } \\
\text { tiškai. Žodis sarkastiškai, } \\
\text { prasminiu lygiu susietas su } \\
\text { susikrimsti, suteikia šiam } \\
\text { veiksmažodžiui ironišką } \\
\text { reikšmės atspalvị. }\end{array}$ \\
\hline $\begin{array}{l}\text { BNS. } \\
\text { Apie pasitraukimą paskelbęs } \\
\text { Ramzanas Kadyrovas: „Šiuo } \\
\text { klausimu sprendimą priims } \\
\text { Vladimiras Putinas“ } \\
\text { https://www.15min.lt/ } \\
\text { naujiena/aktualu/pasaulis/ } \\
\text { apie-pasitraukima-paskel- } \\
\text { bes-ramzanas-kadyrovas- } \\
\text { siuo-klausimu-sprendima- } \\
\text { priims-vladimiras-putinas- } \\
\text { 57-590159?comments\&copied } \\
2016 \text { m. kovo } 2 \text { d. }\end{array}$ & $\begin{array}{l}\text { „Kai kalbu, kad esu } \\
\text { Putino pėstininkas, } \\
\text { tai - ne šiaip žodžiai, } \\
\text { tai tvirta mano pozi- } \\
\text { cija. Tai reiškia, kad } \\
\text { nesvarbu, ar dirbsiu } \\
\text { šiame poste, ar ne, } \\
\text { esu ištikimas prezi- } \\
\text { dentui Vladimirui } \\
\text { Putinui“, - aiškino } \\
\text { Čečènijos lyderis. }\end{array}$ & $\begin{array}{l}\text { Valdo Kadyrovą. } \\
\text { Putino péstininkas } R \text {. Ka- } \\
\text { dyrovas - politine realija, } \\
\text { kurios prasminis laukas } \\
\text { labai neigiamas, nes jis su } \\
\text { tarptautiniu terorizmu ir } \\
\text { nusikaltimais savo tautai } \\
\text { siejamas asmuo. }\end{array}$ \\
\hline $\begin{array}{l}\text { Edwardas Lucasas. } \\
\text { Edwardas Lucasas: Ką Plato- } \\
\text { nas pasakytų apie Putiną? } \\
\text { https://www.15min. } \\
\underline{\text { lt/naujiena/aktualu/ }} \\
\underline{\text { komentarai/edwardas- }} \\
\text { lucasas-ka-platonas-pasaky- } \\
\text { tu-apie-putina-500-603693 } \\
\text { ?comments\&copied } \\
2016 \text { m. kovo } 31 \mathrm{~d} .\end{array}$ & $\begin{array}{l}\text { Tai dvelkia putiniz- } \\
\text { mu: stiprus yra teisus, } \\
\text { o taisyklès tėra veid- } \\
\text { mainiška nesąmonè. }\end{array}$ & $\begin{array}{l}\text { Pripažįsta tik galią. } \\
\text { Putinizmas - naujadaras, } \\
\text { reiškiantis galios teisę prieš } \\
\text { taisykles ir demokratiją. }\end{array}$ \\
\hline
\end{tabular}




\begin{tabular}{|c|c|c|}
\hline $\begin{array}{l}\text { Straipsnio / informacijos / } \\
\text { pranešimo šaltinis, pavadini- } \\
\text { mas, internetinè nuoroda ir } \\
\text { paskelbimo data }\end{array}$ & Citata & $\begin{array}{l}\text { Ideologinès V. Putino } \\
\text { naratyvo implikacijos }\end{array}$ \\
\hline $\begin{array}{l}\text { 15min.lt. } \\
\text { Vladimiro Putino draugas tai- } \\
\text { kosi ị Rusijos aviacijos milžinę } \\
\text { https://www.15min.lt/ } \\
\text { verslas/naujiena/bendroves/ } \\
\text { vladimiro-putino-draugas- } \\
\text { taikosi-i-rusijos-aviacijos-mil- } \\
\text { zine-663-593983?copied } \\
2016 \mathrm{~m} . \text { kovo } 10 \mathrm{~d} .\end{array}$ & & $\begin{array}{l}\text { V. Putino vertinimo atžvil- } \\
\text { giu informacija nekono- } \\
\text { tuota. }\end{array}$ \\
\hline $\begin{array}{l}\text { Indre Anskaitytė, LRT radijo } \\
\text { laida „Pasaulio laikas“. } \\
\text { https://www.15min.lt/ } \\
\text { naujiena/aktualu/pasaulis/ } \\
\text { kremliaus-kritike-l-sevcova-v- } \\
\text { putino-populiarumas-rusijoje- } \\
\text { tera-klastote-57-595887?copied } \\
2016 \text { m. kovo } 14 \text { d. }\end{array}$ & $\begin{array}{l}\text { Vladimiro Putino } \\
\text { populiarumas tèra } \\
\text { klastotė } \\
<\ldots>\text { ar šioje situacija } \\
\text { [riktas originaliame } \\
\text { tekste, turi būti situa- } \\
\text { cijoje }-J . Z \text {. pastaba] } \\
\text { verta demonizuoti tik } \\
\text { poną Putiną <...> }\end{array}$ & $\begin{array}{l}\text { Apgavikas. } \\
\text { Klastote - neigiama kono- } \\
\text { tacija. } \\
\text { Demonizuoti - šis veiksma- } \\
\text { žodis turi paniekos atspalvi, } \\
\text { kurị sustiprina ir ironiškai } \\
\text { vartojamas V. Putinui pri- } \\
\text { skirtas atributas - ponas. }\end{array}$ \\
\hline $\begin{array}{l}15 \text { min.lt. } \\
\text { R. Kadyrovo kalbos apie } \\
\text { traukimąsi: V. Putino sukurtas } \\
\text { monstras šantažuoja savo } \\
\text { kūrèją https://www.15min.lt/ } \\
\text { naujiena/aktualu/pasaulis/r- } \\
\text { kadyrovo-kalbos-apie-trauki- } \\
\text { masi-v-putino-sukurtas-mons- } \\
\text { tras-santazuoja-savo-kureja- } \\
57-589529 \text { ? comments\&copied } \\
2016 \mathrm{~m} \text {. kovo } 1 \mathrm{~d} \text {. }\end{array}$ & $\begin{array}{l}\text { R. Kadyrovas yra } \\
\text { V. Putino Frankenš- } \\
\text { teinas. }\end{array}$ & $\begin{array}{l}\text { Politinių monstrų kūrèjas. } \\
\text { Frankenšteinas - stipri, } \\
\text { labai neigiamą įspūdị suku- } \\
\text { rianti stilistinè figūra. }\end{array}$ \\
\hline $\begin{array}{l}\text { 15min.lt. } \\
\text { Dūris ị separatizmo burbulą: } \\
\text { Rytų Ukrainą valdo Vladimiro } \\
\text { Putino pasiuntiniai } \\
\text { https://www.15min.lt/ } \\
\text { naujiena/aktualu/pasaulis/ } \\
\text { duris-i-separatizmo-burbu- } \\
\text { la-rytu-ukraina-valdo-vla- } \\
\text { dimiro-putino-pasiuntiniai- } \\
\text { 2016 } 603317 \text { ?. komments\&copied }\end{array}$ & $\begin{array}{l}\text { V. Putinas okupuotą } \\
\text { Rytų Ukrainą } \\
\text { patikejo artimiems } \\
\text { patikètiniams. }\end{array}$ & $\begin{array}{l}\text { Okupantas. } \\
\text { Patikéti - „paskirti } \\
\text { valdyti“ -aiški nuoroda ị } \\
\text { V. Putino asmeninę atsa- } \\
\text { komybę dèl Rytų Ukrainos } \\
\text { okupacijos. }\end{array}$ \\
\hline
\end{tabular}




\begin{tabular}{|c|c|c|}
\hline $\begin{array}{l}\text { Straipsnio / informacijos / } \\
\text { pranešimo šaltinis, pavadini- } \\
\text { mas, internetinè nuoroda ir } \\
\text { paskelbimo data }\end{array}$ & Citata & $\begin{array}{l}\text { Ideologinės V. Putino } \\
\text { naratyvo implikacijos }\end{array}$ \\
\hline $\begin{array}{l}15 \text { min.lt. } \\
\text { Vladimiras Putinas ịsake nuo } \\
\text { kovo } 15 \text {-osios Rusijos pajè- } \\
\text { goms trauktis iš Sirijos } \\
\text { https://www.15min.lt/ } \\
\text { naujiena/aktualu/pasaulis/ } \\
\text { vladimiras-putinas-isake- } \\
\text { nuo-kovo-15-osios-rusijos- } \\
\text { pajegoms-trauktis-is-sirijos- } \\
\text { 57-595843?copied } \\
2016 \mathrm{~m} . \text { kovo } 14 \mathrm{~d} \text {. }\end{array}$ & & $\begin{array}{l}\text { V. Putino vertinimo atžvil- } \\
\text { giu informacija nekono- } \\
\text { tuota. }\end{array}$ \\
\hline $\begin{array}{l}\text { Lrt.lt. } \\
\text { Vladimiro Putino propaganda } \\
\text { ir svajoness apie Jaltą } \\
\text { https://www.15min.lt/ } \\
\text { naujiena/aktualu/pasaulis/ } \\
\text { vladimiro-putino-propa- } \\
\text { ganda-ir-svajones-apie-jalta- } \\
\text { 57-599283?comments\&copied } \\
2016 \mathrm{~m} \text {. kovo } 22 \mathrm{~d} \text {. }\end{array}$ & & $\begin{array}{l}\text { Žr. komentarus apie tokią } \\
\text { pačią publikaciją Delfi.lt } \\
\text { portale. }\end{array}$ \\
\hline $\begin{array}{l}\text { 15min.lt. } \\
\text { Naujoji Vladimiro Putino } \\
\text { pasija - buvusi žiniasklaidos } \\
\text { magnato žmona? } \\
\text { https://www.15min.lt/ } \\
\text { naujiena/aktualu/pasaulis/ } \\
\text { naujoji-vladimiro-puti- } \\
\underline{\text { no-pasija-buvusi-zinias- }} \\
\underline{\text { klaidos-magnato-zmona- }} \\
\underline{57-604175 \text { ?comments\&copied }} \\
2016 \mathrm{~m} \text {. kovo } 31 \mathrm{~d} \text {. }\end{array}$ & $\begin{array}{l}\text { Vienas V. Putinui } \\
\text { artimas šaltinis apie } \\
\text { ¡žymybių gyvenimus } \\
\text { rašančiam žurnalui } \\
\text { „Us Weekly“ paliu- } \\
\text { dijo, kad politiko } \\
\text { santykiai su W. Deng } \\
\text { yra rimti. }\end{array}$ & $\begin{array}{l}\text { İžymybe். } \\
\text { Ižymybe - teigiamos kono- } \\
\text { tacijos žodis. }\end{array}$ \\
\hline
\end{tabular}




\begin{tabular}{|c|c|c|}
\hline $\begin{array}{l}\text { Straipsnio / informacijos / } \\
\text { pranešimo šaltinis, pavadini- } \\
\text { mas, internetinė nuoroda ir } \\
\text { paskelbimo data }\end{array}$ & Citata & $\begin{array}{l}\text { Ideologinės V. Putino } \\
\text { naratyvo implikacijos }\end{array}$ \\
\hline $\begin{array}{l}\text { Paulius Gritenas. } \\
\text { Buvęs Vladimiro Putino pade- } \\
\text { jëjas: „Kitas Rusijos taikinys - } \\
\text { Baltarusija“ } \\
\text { https://www.15min.lt/ } \\
\text { naujiena/aktualu/pasaulis/ } \\
\text { buves-vladimiro-puti- } \\
\text { no-padejejas-kitas-rusi- } \\
\text { jos-taikinys-baltarusija- } \\
\text { 57-594405?comments\&copied } \\
2016 \text { m. kovo } 10 \text { d. }\end{array}$ & $\begin{array}{l}\text { Vilniuje vykstančia- } \\
\text { me Laisvos Rusijos } \\
\text { forume aptarta Vla- } \\
\text { dimiro Putino režimo } \\
\text { politika tarptautinio } \\
\text { saugumo kontekste. }\end{array}$ & $\begin{array}{l}\text { Putinas - autoritarinis } \\
\text { vadovas. } \\
\text { Režimas - stiprios konota- } \\
\text { cijos žodis, kuris nurodo, } \\
\text { kad valdymo būdas yra } \\
\text { nepriimtinas. }\end{array}$ \\
\hline $\begin{array}{l}\text { 15min.lt. } \\
\text { Barackas Obama paviešino } \\
\text { pokalbi, kuriame pasišaipė iš } \\
\text { Vladimiro Putino } \\
\text { https://www.15min.lt/ } \\
\text { naujiena/aktualu/pasaulis/ } \\
\text { barackas-obama-paviesi- } \\
\text { no-pokalbi-kuriame-pasi- } \\
\text { saipe-is-vladimiro-putino- } \\
\text { 57-602717?comments\&copied } \\
2016 \mathrm{~m} . \text { kovo } 29 \mathrm{~d} .\end{array}$ & $\begin{array}{l}\text { „Skirtingai nei tu, } \\
\text { Vladimirai, aš nere- } \\
\text { daguoju straipsnių } \\
\text { prieš paskelbi- } \\
\text { mą“, - V. Putinui } \\
\text { atsakè B. Obama. Ši } \\
\text { istorija sukėlè gausius } \\
\text { plojimus ir salès } \\
\text { juoką. }\end{array}$ & $\begin{array}{l}\text { Putinas prieš spaudos } \\
\text { laisvę. } \\
\text { Redaguoti - perkeltine } \\
\text { prasme - taisyti tai, kas } \\
\text { parašyta kito. Citatos kon- } \\
\text { tekste tai nuoroda ị žodžio } \\
\text { laisvės varžymą. }\end{array}$ \\
\hline $\begin{array}{l}\text { 15min.lt. } \\
\text { Po Vladimiro Putino pareiš- } \\
\text { kimo iš Sirijos traukiasi ir } \\
\text { Libano „Hezbollah“ } \\
\text { https://www.15min.lt/ } \\
\text { naujiena/aktualu/pasaulis/po- } \\
\text { vladimiro-putino-pareiskimo- } \\
\text { is-sirijos-traukiasi-ir-libano- } \\
\text { hezzbolah-57-596253?copied } \\
2016 \mathrm{~m} . \text { kovo } 15 \mathrm{~d} \text {. }\end{array}$ & & $\begin{array}{l}\text { V. Putino vertinimo atžvil- } \\
\text { giu informacija nekono- } \\
\text { tuota. }\end{array}$ \\
\hline
\end{tabular}




\begin{tabular}{|c|c|c|}
\hline $\begin{array}{l}\text { Straipsnio / informacijos / } \\
\text { pranešimo šaltinis, pavadini- } \\
\text { mas, internetinè nuoroda ir } \\
\text { paskelbimo data }\end{array}$ & Citata & $\begin{array}{l}\text { Ideologinės V. Putino } \\
\text { naratyvo implikacijos }\end{array}$ \\
\hline $\begin{array}{l}\text { 15min.lt. } \\
\text { Vladimiru Putinu besido- } \\
\text { minčius žurnalistus Kremlius } \\
\text { kaltina išpuoliu prieš Rusiją } \\
\text { https://www.15min.lt/ } \\
\text { naujiena/aktualu/pasaulis/ } \\
\text { vladimiru-putinu-besidomin- } \\
\text { cius-zurnalistus-kremlius- } \\
\text { kaltina-ispuoliu-pries-rusija- } \\
57-604015 \text { ?copied } \\
2016 \text { m. kovo } 31 \mathrm{~d} .\end{array}$ & $\begin{array}{l}\text { Oficialioji Maskva } \\
\text { ir toliau nerimsta, } \\
\text { kalbėdama apie } \\
\text { menamą „informa- } \\
\text { cinę ataką“ prieš } \\
\text { Vladimirą Putiną bei } \\
\text { jo aplinką. V. Putino } \\
\text { ryšiais besidominčius } \\
\text { žurnalistus Kremlius } \\
\text { jau kaltina bandymu } \\
\text { destabilizuoti Rusiją } \\
\text { [riktas (trūksta kab- } \\
\text { lelio) originaliame } \\
\text { tekste - J. Z. pastaba] } \\
\text { praneša rbc.ru. }\end{array}$ & $\begin{array}{l}\text { Putinas prieš spaudos } \\
\text { laisvę. } \\
\text { Kaltinti - neigiamas, } \\
\text { pragmatiniu požiūriu suas- } \\
\text { menintas veiksmažodis. } \\
\text { Tai kitu aspektu pateikta } \\
\text { informacija, jau pristatyta } \\
\text { straipsnyje „Keistas Krem- } \\
\text { liaus žingsnis: prabilo apie } \\
\text { artimiausios Vladimiro } \\
\text { Putino aplinkos turtų me- } \\
\text { džioklę“, } 2016 \text { m. kovo } 29 \text { d., } \\
\text { 15min.lt. }\end{array}$ \\
\hline $\begin{array}{l}\text { 15min.lt. } \\
\text { Vladimiras Putinas paskelbė, } \\
\text { kiek milijardų Rusija išleido } \\
\text { karui Sirijoje } \\
\text { https://www.15min.lt/ } \\
\text { naujiena/aktualu/pasaulis/ } \\
\text { rusija-karui-sirijoje-islei- } \\
\text { do-33-milijardus-rubliu- } \\
\text { 57-597423? copied }\end{array}$ & $\begin{array}{l}\text { Pasak V. Putino, šie } \\
\text { išleisti } 33 \text { milijardai } \\
\text { atsipirko, nes buvo } \\
\text { garantuotas ne tik } \\
\text { Sirijos, bet ir Rusijos } \\
\text { gyventojų saugumas } \\
\text { bei užkirstas kelias } \\
\text { galimam teroristų } \\
\text { antplūdžiui. }\end{array}$ & $\begin{array}{l}\text { Garantuoja saugumą. } \\
\text { Kovojantis su terorizmu. } \\
\text { Saugumas, garantuoti - tei- } \\
\text { giamos konotacijos žodžiai. }\end{array}$ \\
\hline $\begin{array}{l}15 \text { min.lt. } \\
\text { Vladimiras Putinas pasisakè } \\
\text { apie dopingo skandalą - kalti- } \\
\text { na pareigūnus } \\
\text { https://www.15min.lt/ } \\
\frac{\text { deuce/naujiena/profesio- }}{\text { nalus-sportas/naujienos/ }} \\
\underline{\text { vladimiras-putinas-pasisa- }} \\
\underline{\text { ke-apie-meldoniumo-skan- }} \\
\text { dala-kaltina-pareigunus- } \\
338-597459 \text { ?copied } \\
2016 \text { m. kovo } 17 \mathrm{~d} .\end{array}$ & $\begin{array}{l}\text { Trečiadienị V. Putinas } \\
\text { dėl dopingo skandalo } \\
\text { pažėrè visą virtinę } \\
\text { pastabų Rusijos spor- } \\
\text { to pareigūnams, kurie } \\
\text { atletų neperspejo dèl } \\
\text { Pasaulinės antidopin- } \\
\text { go agentūros (WADA) } \\
\text { atnaujinto juodojo } \\
\text { sąrašo. }\end{array}$ & $\begin{array}{l}\text { Rūpinasi sportininkais. } \\
\text { Žerti - vaizdingas buitinio } \\
\text { stiliaus veiksmažodis, turin- } \\
\text { tis energijos fonosemantinę } \\
\text { konotaciją, suasmeninantis } \\
\text { santykį su informacijos } \\
\text { subjektu. }\end{array}$ \\
\hline
\end{tabular}




\begin{tabular}{|c|c|c|}
\hline $\begin{array}{l}\text { Straipsnio / informacijos / } \\
\text { pranešimo šaltinis, pavadini- } \\
\text { mas, internetinè nuoroda ir } \\
\text { paskelbimo data }\end{array}$ & Citata & $\begin{array}{l}\text { Ideologinės V. Putino } \\
\text { naratyvo implikacijos }\end{array}$ \\
\hline 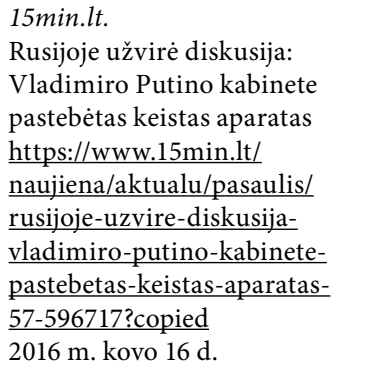 & & $\begin{array}{l}\text { V. Putino vertinimo atžvil- } \\
\text { giu informacija nekono- } \\
\text { tuota. }\end{array}$ \\
\hline
\end{tabular}

\section{2 lentele. Semantinès ir prasminès $\mathbf{V}$. Putino naratyvo nuorodos}

\begin{tabular}{|c|c|c|}
\hline $\begin{array}{l}\text { Straipsnio / informacijos / } \\
\text { pranešimo šaltinis, pavadini- } \\
\text { mas, internetinè nuoroda ir } \\
\text { paskelbimo data }\end{array}$ & Citata & $\begin{array}{l}\text { Semantinès ir prasmi- } \\
\text { nès V. Putino naratyvo } \\
\text { nuorodos }\end{array}$ \\
\hline I. www.delfi.lt & www.delfi.lt & www.delfi.lt \\
\hline $\begin{array}{l}\text { „Bloomberg“ } \\
\text { „Bloomberg“: ES reikia plano, } \\
\text { kaip kovoti su Putino „troliais“ } \\
\text { https://www.delfi.lt/verslas/ } \\
\text { bloomberg/bloomberg-es-rei- } \\
\text { kia-plano-kaip-kovoti-su-puti- } \\
\underline{\text { no-troliais.d?id=80719079 }}\end{array}$ & $\begin{array}{l}\text { Rusijos prezidento } \\
\text { Vladimiro Putino } \\
\text { tikslas - padidinti } \\
\text { euroskeptikų bloką } \\
\text { naujajame Europos } \\
\text { Parlamente, kad šis } \\
\text { silpnintų ES sanglau- } \\
\text { dą ir tarnautų Rusijos } \\
\text { interesams. }\end{array}$ & $\begin{array}{l}\text { Putinas tarnauja Rusijos } \\
\text { interesams. } \\
\text { Teigiamas žodis tarnauti, } \\
\text { vadinasi, būti nesavanau- } \\
\text { diškam. }\end{array}$ \\
\hline $\begin{array}{l}\text { BNS. } \\
\text { Porošenka: Putinas - vieninte- } \\
\text { lis mano oponentas } \\
\text { https://www.delfi.lt/news/ } \\
\text { daily/world/porosenka- } \\
\text { putinas-vienintelis-mano- } \\
\text { oponentas.d?id=80727345 } \\
2019 \mathrm{~m} . \text { kovo } 27 \mathrm{~d} .\end{array}$ & $\begin{array}{l}\text { „Mano sąjungininkai - } \\
\text { Ukrainos žmonės. Kas } \\
\text { mano oponentas? } \\
\text { Mano oponentas - ir } \\
\text { aš to nesigediju, sakau } \\
\text { atviru tekstu - yra } \\
\text { vienintelis, nes kiti bijo } \\
\text { tai daryti. Mano opo- } \\
\text { nentas yra Putinas“, - } \\
\text { televizijai ICTV saké } \\
\text { P. Porošenka. }\end{array}$ & $\begin{array}{l}\text { Putinas drąsus oponentas, } \\
\text { nes kiti bijo būti P. Porošen- } \\
\text { kos oponentais. } \\
\text { Žodis oponentas neturi } \\
\text { neigiamos konotacijos, } \\
\text { kurią turi, pvz., sinonimas } \\
\text { priešininkas (plg. giminišką } \\
\text { žodị priešas). }\end{array}$ \\
\hline
\end{tabular}




\begin{tabular}{|c|c|c|}
\hline $\begin{array}{l}\text { Straipsnio / informacijos / } \\
\text { pranešimo šaltinis, pavadini- } \\
\text { mas, internetinė nuoroda ir } \\
\text { paskelbimo data }\end{array}$ & Citata & $\begin{array}{l}\text { Semantinès ir prasmi- } \\
\text { nės V. Putino naratyvo } \\
\text { nuorodos }\end{array}$ \\
\hline $\begin{array}{l}\text { Leonid Bershidsky, „Bloom- } \\
\text { berg“. } \\
\text { Ekspertas: Krymas Putiną } \\
\text { ìstūmè i spąstus } \\
\text { https://www.delfi.lt/news/ } \\
\text { daily/world/ekspertas- } \\
\text { krymas-putina-istume-i- } \\
\text { spastus.d?id=80646267 } \\
2019 \text { m. kovo } 17 \text { d. }\end{array}$ & $\begin{array}{l}\text { Po penkerių metų } \\
\text { Rusijos prezidentas } \\
\text { Vladimiras Putinas } \\
\text { moka už Krymą. } \\
\text { Jo pernelyg didelis } \\
\text { pasitikejjimas po } \\
\text { sėkmingos aneksijos } \\
\text { ìstūmè jị i spąstus, } \\
\text { kur jis neteko derybi- } \\
\text { nès galios. }\end{array}$ & $\begin{array}{l}\text { Putiną lydèjo sėkmė, nes } \\
\text { aneksija buvo sékminga. } \\
\text { Vertinama iš V. Putino } \\
\text { pozicijų. } \\
\text { Aneksiją neigiamai vertinant } \\
\text { labiau tiktų neutralus žodis } \\
\text { juvkusi, nes žodžio sékminga } \\
\text { pamatinis žodis sèkmé yra } \\
\text { vienas teigiamiausių sociali- } \\
\text { nès būsenos įvardijimų. }\end{array}$ \\
\hline $\begin{array}{l}\text { Rimvydas Valatka. } \\
\text { Rusofobas Putinas } \\
\text { https://www.delfi.lt/news/rin- } \\
\text { gas/lit/rimvydas-valatka-ruso- } \\
\text { fobas-putinas.d?id=80578095 } \\
2019 \text { m. kovo } 19 \mathrm{~d} .\end{array}$ & \begin{tabular}{|l|} 
Tai, ko Europoje po \\
Helsinkio nebūtų drị- \\
susi net komunistinė \\
SSRS, padarè formaliai \\
demokratinė, o de fac- \\
to mafijos autoriteto \\
Putino valdoma Ru- \\
sija. Kas pasikeite per \\
penkmeti po Krymo \\
užgrobimo?
\end{tabular} & $\begin{array}{l}\text { Rusofobas Putinas yra } \\
\text { de facto mafijos autorite- } \\
\text { tas. Krymą užgrobė. } \\
\text { Tekste ir daugiau neigiamą } \\
\text { V. Putino įvaizdị formuo- } \\
\text { jančių citatų. } \\
\text { Plg. semantinę žodžių } \\
\text { junginių konotaciją: } \\
\text { sékminga aneksija: Krymo } \\
\text { užgrobimas. }\end{array}$ \\
\hline $\begin{array}{l}\text { Reuters. } \\
\text { Putinas savo įvaizdị stiprino } \\
\text { pasikinkęs* žirgą } \\
\text { https://www.delfi.lt/video/ } \\
\text { aktualijos/putinas-savo- } \\
\text { ivaizdi-stiprino-pasikinkes- } \\
\underline{\text { zirga.d?id=80566933 }} \\
2019 \mathrm{~m} . \text { kovo } 8 \mathrm{~d} .\end{array}$ & $\begin{array}{l}\text { Per } 19 \text { metų valdžioje } \\
\text { V. Putinas aktyviai } \\
\text { propaguoja „mačo“ } \\
\text { ịvaizdį. Vien ko vertos } \\
\text { nuotraukos, kuriose - } \\
\text { V. Putinas pusnuogis } \\
\text { jodineja Sibire, V. Pu- } \\
\text { tinas neria j̇ ledinị } \\
\text { vandenị ar V. Putinas } \\
\text { pilotuoja ugniagesių } \\
\text { lèktuvą. } \\
\text { Po pasijodinėjimo } \\
\text { V. Putinas raitajai poli- } \\
\text { cijai padovanojo žirgą, } \\
\text { vardu Auksinis spin- } \\
\text { dulys, skelbia Rusijos } \\
\text { naujienų agentūros. }\end{array}$ & $\begin{array}{l}\text { Putinas dosnus sveikuolis. } \\
\text { Vien tik padovanoto (labai } \\
\text { malonių asociacijų keliantis } \\
\text { žodis) žirgo vardas Auksinis } \\
\text { Spindulys (sąsajos su turtu } \\
\text { ir šviesa) turi skaitytoją } \\
\text { nuteikti teigiamai. }\end{array}$ \\
\hline
\end{tabular}

* Semantikos klaida: tekste kalbama apie jodinèjantị V. Putiną 


\begin{tabular}{|c|c|c|}
\hline $\begin{array}{l}\text { Straipsnio / informacijos / } \\
\text { pranešimo šaltinis, pavadini- } \\
\text { mas, internetinė nuoroda ir } \\
\text { paskelbimo data }\end{array}$ & Citata & $\begin{array}{l}\text { Semantinès ir prasmi- } \\
\text { nès V. Putino naratyvo } \\
\text { nuorodos }\end{array}$ \\
\hline $\begin{array}{l}\text { BNS. } \\
\text { Putinas stabdo Rusijos dalyva- } \\
\text { vimą INF sutartyje } \\
\text { https://www.delfi.lt/news/ } \\
\text { daily/world/putinas-stab- } \\
\text { do-rusijos-dalyvavima-inf-- } \\
\underline{\text { sutartyje.d?id=80525049 }} \\
2019 \text { m. kovo } 4 \text { d. }\end{array}$ & & $\begin{array}{l}\text { V. Putino vertinimo atžvil- } \\
\text { giu informacija nekono- } \\
\text { tuota. }\end{array}$ \\
\hline $\begin{array}{l}\text { Evgenia Pismennaya, Anna } \\
\text { Andrianova, „Bloomberg“. } \\
\text { Putinas tyliai stato finansinę } \\
\text { tvirtovę - laukia nauji mūšiai } \\
\text { su Vakarais } \\
\text { https://www.delfi.lt/news/ } \\
\underline{\text { daily/world/putinas-ty- }} \\
\underline{\text { liai-stato-finansine-tvirto- }} \\
\underline{\text { ve-laukia-nauji-musiai-su- }} \\
\text { vakarais.d?id=80483423 } \\
2019 \text { m. kovo } 4 \text { d. }\end{array}$ & $\begin{array}{l}\text { V. Putinas tyliai stato } \\
\text { finansinę tvirtovę, } \\
\text { kuri, pasak vyriau- } \\
\text { sybės pareigūnų ir } \\
\text { Kremliaus patarèjų, } \\
\text { apsaugos šalies ekono- } \\
\text { miką nuo gresiančių } \\
\text { „pabūklų salvių“ ir tuo } \\
\text { pačiu toliau vers JAV } \\
\text { ir jos sąjungininkes } \\
\text { spèlioti dèl Rusijos } \\
\text { karinių pajègumų ir } \\
\text { ketinimų. }\end{array}$ & $\begin{array}{l}\text { Turtingas ir stiprus vei- } \\
\text { kėjas (stato tvirtovę, ne bet } \\
\text { kokią, o finansinę). } \\
\text { Tikslas - apsaugoti Rusiją. } \\
\text { Tvirtove - teigiamos } \\
\text { konotacijos žodis, turintis } \\
\text { stiprumo ir saugumo semų. } \\
\text { Veiksmažodis apsaugoti, } \\
\text { kaip ir jau minėtas tarnauti, } \\
\text { turi teigiamą socialinę } \\
\text { konotaciją. }\end{array}$ \\
\hline II. $\quad$ www.lrytas.lt & www.lrytas.lt & www.lrytas.lt \\
\hline $\begin{array}{l}\text { Lrytas.lt. } \\
\text { Atskleide, koks yra V. Putino } \\
\text { kepamas firminis šašlykas ir } \\
\text { kuo ji užgeria } \\
\text { https://www.lrytas.lt/ } \\
\text { pasaulis/marga-plane- } \\
\underline{\text { ta/2019/03/31/news/ }} \\
\text { atskleide-koks-yra-v-putino- } \\
\text { kepamas-firminis-saslykas-ir- } \\
\text { kuo-ji-uzgeria-9790360/?utm } \\
\text { source=lrExtraLinks\&utm } \\
\text { campaign=Copy\&utm } \\
\text { medium=Copy } \\
2019 \mathrm{~m} . \text { kovo } 31 \mathrm{~d} .\end{array}$ & $\begin{array}{l}\text { Rusijos prezidento } \\
\text { Vladimiro Putino, } \\
\text { kurị, pasak jo atstovo } \\
\text { spaudai Dmitrijaus } \\
\text { Peskovo, pripažįsta } \\
\text { ir gerbia net meškos } \\
\text { ir laukinès ožkos, } \\
\text { ịvaizdžio formavimo } \\
\text { kampanija tęsiasi. }\end{array}$ & $\begin{array}{l}\text { Putinas turi stiprų auto- } \\
\text { ritetą. Pripažinti, gerbti } \\
\text { ypač teigiamos konotacijos } \\
\text { veiksmažodžiai. }\end{array}$ \\
\hline
\end{tabular}




\begin{tabular}{|c|c|c|}
\hline $\begin{array}{l}\text { Straipsnio / informacijos / } \\
\text { pranešimo šaltinis, pavadini- } \\
\text { mas, internetinė nuoroda ir } \\
\text { paskelbimo data }\end{array}$ & Citata & $\begin{array}{l}\text { Semantinès ir prasmi- } \\
\text { nès V. Putino naratyvo } \\
\text { nuorodos }\end{array}$ \\
\hline 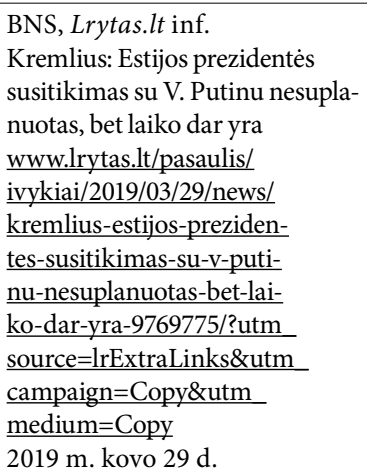 & & $\begin{array}{l}\text { V. Putino vertinimo atžvil- } \\
\text { giu informacija nekono- } \\
\text { tuota. }\end{array}$ \\
\hline $\begin{array}{l}\text { Lrytas.lt. } \\
\text { Dopingo skandaluose iklimpu- } \\
\text { siems Rusijos sportininkams - } \\
\text { V. Putino perspejimas } \\
\text { www.lrytas.lt/sportas/ } \\
\text { startai/2019/03/27/news/ } \\
\text { dopingo-skandaluose- } \\
\text { iklimpusiems-rusijos-spor- } \\
\text { tininkams-v-putino-pers- } \\
\text { pejimas-9743375/?utm } \\
\text { source=lrExtraLinks\&utm } \\
\text { campaign=Copy\&utm } \\
\text { medium=Copy } \\
2019 \text { m. kovo } 27 \text { d. }\end{array}$ & $\begin{array}{l}\text { „Turime pasistengti, } \\
\text { kad nesuteiktume } \\
\text { preteksto tiems, } \\
\text { kurie sportą naudoja } \\
\text { kaip politinị ịrankị, } \\
\text { nukreiptą prieš mūsų } \\
\text { sportininkus“, - teigè } \\
\text { Rusijos vadovas. }\end{array}$ & $\begin{array}{l}\text { Putinas už švarų sportą. } \\
\text { Nesuteikti preteksto - } \\
\text { rūpesčio prasminị elementą } \\
\text { turintis žodžių junginys. }\end{array}$ \\
\hline $\begin{array}{l}\text { BNS, Lrytas.lt inf. } \\
\text { P. Porošenka: V. Putinas - vie- } \\
\text { nintelis mano oponentas } \\
\text { www.lrytas.lt/pasaulis/ } \\
\text { ivykiai/2019/03/27/news/p- } \\
\text { porosenka-v-putinas-vienintelis- } \\
\text { mano-oponentas-9736101/?utm } \\
\text { source=lrExtraLinks\&utm } \\
\text { campaign=Copy\&utm } \\
\text { medium=Copy } \\
2019 \text { m. kovo } 27 \text { d. }\end{array}$ & & $\begin{array}{l}\text { Žr. komentarus apie tokią } \\
\text { pačią publikaciją Delfi.lt } \\
\text { portale. }\end{array}$ \\
\hline
\end{tabular}




\begin{tabular}{|c|c|c|}
\hline $\begin{array}{l}\text { Straipsnio / informacijos / } \\
\text { pranešimo šaltinis, pavadini- } \\
\text { mas, internetinė nuoroda ir } \\
\text { paskelbimo data }\end{array}$ & Citata & $\begin{array}{l}\text { Semantinès ir prasmi- } \\
\text { nès V. Putino naratyvo } \\
\text { nuorodos }\end{array}$ \\
\hline $\begin{array}{l}\text { BNS, Lrytas.lt inf. } \\
\text { Rusijos komunistai protestuoja } \\
\text { prieš Kremliaus politiką ir } \\
\text { V. Putino valdymą } \\
\text { https://www.lrytas.lt/ } \\
\text { pasaulis/ivykiai/2019/03/23/ } \\
\text { news/rusijos-komunistai- } \\
\text { protestuoja-pries-krem- } \\
\text { liaus-politika-ir-v-putino- } \\
\text { valdyma-9692927/?utm } \\
\text { source=lrExtraLinks\&utm } \\
\text { campaign=Copy\&utm } \\
\text { medium=Copy } \\
2019 \text { m. kovo } 23 \text { d. }\end{array}$ & $\begin{array}{l}\text { Keli tūkstančiai } \\
\text { Rusijos komunistų } \\
\text { partijos šalininkų } \\
\text { šeštadienį Maskvoje } \\
\text { protestavo prieš } \\
\text { vyriausybės politiką, } \\
\text { o kai kurie mitingo } \\
\text { dalyviai užsipuolè } \\
\text { prezidentą Vladimirą } \\
\text { Putiną, reikalau- } \\
\text { dami jo asmeninės } \\
\text { atsakomybės dėl išsi- } \\
\text { kerojusios korupcijos } \\
\text { ir kainų augimo. }\end{array}$ & $\begin{array}{l}\text { Putinas palaiko korupciją } \\
\text { ir skatina kainų augimą. } \\
\text { Korupcija ir kainų augimas } \\
\text { ypač neigiamai suvokiamas } \\
\text { žodis ir žodžių junginys. } \\
\text { Neigiamam V. Putino ver- } \\
\text { tinimui šioje publikacijoje } \\
\text { tam tikrą ambivalentišku- } \\
\text { mą suteikia tai, kad apie } \\
\text { ịvykị kalba komunistai, o } \\
\text { šis žodis lietuvių kalboje } \\
\text { turi išskirtinai neigiamą } \\
\text { konotaciją. }\end{array}$ \\
\hline $\begin{array}{l}\text { BNS, Lrytas.lt inf. } \\
\text { V. Putinas lankosi prieš } \\
\text { penkerius metus aneksuotame } \\
\text { Kryme } \\
\text { www.lrytas.lt/pasaulis/ } \\
\text { ivykiai/2019/03/18/news/v- } \\
\text { putinas-lankosi-pries-pen- } \\
\text { kerius-metus-aneksuota- } \\
\text { me-kryme-9629786/?utm_- } \\
\text { source=lrExtraLinks\&utm } \\
\text { campaign=Copy\&utm } \\
\text { medium=Copy } \\
2019 \text { m. kovo } 18 \mathrm{~d} .\end{array}$ & & $\begin{array}{l}\text { V. Putino vertinimo atžvil- } \\
\text { giu informacija nekono- } \\
\text { tuota. }\end{array}$ \\
\hline $\begin{array}{l}\text { BNS, Lrytas.lt inf. } \\
\text { V. Putinas pasirašè melagingas } \\
\text { naujienas draudžiantị įstatymą } \\
\text { https://www.lrytas.lt/ } \\
\text { pasaulis/ivykiai/2019/03/18/ } \\
\text { news/v-putinas-pasirase-mela- } \\
\text { gingas-naujienas-draudzianti- } \\
\text { istatyma-9629223/ } \\
2019 \mathrm{~m} . \text { kovo } 18 \mathrm{~d} .\end{array}$ & $\begin{array}{l}\text { Valdžios troškimas } \\
\text { užkimšti burną savo } \\
\text { pavaldiniams yra } \\
\text { labai senas, gèdingas } \\
\text { ir beprasmis. }\end{array}$ & $\begin{array}{l}\text { Putino vyriausybė stengia- } \\
\text { si užgniaužti žodžio laisvę. } \\
\text { Užkimšti burnq - stiprios } \\
\text { neigiamos konotacijos } \\
\text { žodžių junginys. }\end{array}$ \\
\hline
\end{tabular}




\begin{tabular}{|c|c|c|}
\hline $\begin{array}{l}\text { Straipsnio / informacijos / } \\
\text { pranešimo šaltinis, pavadini- } \\
\text { mas, internetinė nuoroda ir } \\
\text { paskelbimo data }\end{array}$ & Citata & $\begin{array}{l}\text { Semantinès ir prasmi- } \\
\text { nès V. Putino naratyvo } \\
\text { nuorodos }\end{array}$ \\
\hline $\begin{array}{l}\text { BNS, Lrytas.lt inf. } \\
\text { V. Putinas ketina Kryme } \\
\text { pamineti pusiasalio aneksijos } \\
\text { penktąsias metines } \\
\text { www.lrytas.lt/pasaulis/ } \\
\text { ivykiai/2019/03/17/news/v- } \\
\text { putinas-ketina-kryme-pamine- } \\
\text { ti-pusiasalio-aneksijos-penk- } \\
\text { tasias-metines-9614641/?utm } \\
\text { source=lrExtraLinks\&utm } \\
\text { campaign=Copy\&utm } \\
\text { medium=Copy }\end{array}$ & & $\begin{array}{l}\text { V. Putino vertinimo atžvil- } \\
\text { giu informacija nekono- } \\
\text { tuota. }\end{array}$ \\
\hline $\begin{array}{l}\text { Lrytas.lt } \\
\text { Rusijoje išdygo antkapis Vladi- } \\
\text { mirui Putinui } \\
\text { https://www.lrytas.lt/pasaulis/ } \\
\text { ivykiai/2019/03/13/news/rusi- } \\
\text { joje-isdygo-antkapis-vladimi- } \\
\underline{\text { rui-putinui-9565531/ }} \\
2019 \mathrm{~m} . \text { kovo } 13 \mathrm{~d} .\end{array}$ & $\begin{array}{l}\text { Tatarstano mieste } \\
\text { Naberežnyje Čelnai } \\
\text { vieno namo kieme } \\
\text { gyventojai pastate } \\
\text { antkapi Rusijos pre- } \\
\text { zidentui V. Putinui ir } \\
\text { apjuosė ji tvorele. }\end{array}$ & $\begin{array}{l}\text { Antkapis gyvam Putinui. } \\
\text { Vaizdingai reiškiamas ne- } \\
\text { pasitenkinimas, noras, kad } \\
\text { V. Putinas būtų palaidotas, } \\
\text { pyktis. } \\
\text { Antkapis - su mirtimi } \\
\text { semantiškai susijęs žodis, } \\
\text { keliantis neigiamų asoci- } \\
\text { acijų. }\end{array}$ \\
\hline $\begin{array}{l}\text { BNS, Lrytas.lt inf. } \\
\text { Austrijos užsienio reikalų mi- } \\
\text { nistrè žada išlaikyti draugiškus } \\
\text { ryšius su Rusija } \\
\text { https://www.lrytas.lt/pasaulis/ } \\
\text { ivykiai/2019/03/12/news/ } \\
\text { austrijos-uzsienio-reikalu-mi- } \\
\text { nistre-zada-islaikyti-draugis- } \\
\text { kus-rysius-su-rusija-9557576/ } \\
2019 \text { m. kovo } 12 \text { d. }\end{array}$ & $\begin{array}{l}\text { Austrijos užsienio } \\
\text { reikalų ministré } \\
\text { Karin Kneissl, kuri } \\
\text { pernai sukėlè kon- } \\
\text { troversiją pakvietusi } \\
\text { rusų prezidentą Vla- } \\
\text { dimirą Putiną ị savo } \\
\text { vestuves, antradienį } \\
\text { Maskvoje pareiškė, } \\
\text { kad Austrija, ne- } \\
\text { paisydama Europos } \\
\text { Sąjungos sankcijų, } \\
\text { nori išlaikyti gerus } \\
\text { ryšius su Rusija. }\end{array}$ & $\begin{array}{l}\text { Putino pakvietimas ị ves- } \\
\text { tuves kelia kontroversiją. } \\
\text { Kontroversija - neigiamos } \\
\text { reikšmės terminas. }\end{array}$ \\
\hline
\end{tabular}




\begin{tabular}{|c|c|c|}
\hline $\begin{array}{l}\text { Straipsnio / informacijos / } \\
\text { pranešimo šaltinis, pavadini- } \\
\text { mas, internetinė nuoroda ir } \\
\text { paskelbimo data }\end{array}$ & Citata & $\begin{array}{l}\text { Semantinès ir prasmi- } \\
\text { nès V. Putino naratyvo } \\
\text { nuorodos }\end{array}$ \\
\hline $\begin{array}{l}\text { Lrytas.lt. } \\
\text { Jaunimu prisidengusi Rusija } \\
\text { žaidžia gudrų žaidimą - prisi- } \\
\text { statė ir V. Putinas } \\
\text { https://www.lrytas.lt/sportas/ } \\
\text { startai/2019/03/09/news/jau- } \\
\text { nimu-prisidengusi-rusija-zai- } \\
\text { dzia-gudru-zaidima-prisistate- } \\
\text { ir-v-putinas-9509855/?utm } \\
\text { source=lrExtraLinks\&utm } \\
\text { campaign=Copy\&utm } \\
\text { medium=Copy } \\
2019 \text { m. kovo } 9 \text { d. }\end{array}$ & $\begin{array}{l}\text { Tai, koks svarbus šis } \\
\text { renginys pasirodè } \\
\text { Rusijai, patvirtina } \\
\text { faktas, kad atidarymo } \\
\text { ceremonijoje pasiro- } \\
\text { dè ir kalbą rěžè pats } \\
\text { šalies prezidentas } \\
\text { Vladimiras Putinas. }\end{array}$ & $\begin{array}{l}\text { Manipuliatorius. } \\
\text { Nepalankumas V. Putinui } \\
\text { atskleistas per neigiamą, } \\
\text { paniekinamą konotaciją tu- } \\
\text { rinti veiksmažodžio sakyti } \\
\text { sinonimą réžti. }\end{array}$ \\
\hline $\begin{array}{l}\text { BNS, Interfax, Lrytas.lt inf. } \\
\text { V. Putinas pernai demaskavo } \\
129 \text { pareigūnus ir } 465 \text { užsienio } \\
\text { agentus } \\
\text { https://www.lrytas.lt/ } \\
\text { pasaulis/ivykiai/2019/03/06/ } \\
\text { news/v-putinas-rusijos-kon- } \\
\text { trzvalgyba-pernai-demaskavo- } \\
\text { 129-pareigunus-ir-465-uzsie- } \\
\text { nio-agentus--9480410/ }\end{array}$ & & $\begin{array}{l}\text { V. Putino vertinimo atžvil- } \\
\text { giu informacija nekono- } \\
\text { tuota. }\end{array}$ \\
\hline $\begin{array}{l}\text { Lryto } T V . \\
\text { Atstovu rūmai reikalauja } \\
\text { duomenų apie D. Trumpo ir } \\
\text { V. Putino pokalbių detales } \\
\text { https://tv.lrytas.lt/zinios/ } \\
\text { pasaulis/2019/03/05/news/ } \\
\text { atstovu-rumai-reikalauja-duo- } \\
\text { menu-apie-d-trumpo-ir-v-pu- } \\
\text { tino-pokalbiu-detales- } 9467146 / \\
2019 \text { m. kovo } 5 \text { d. }\end{array}$ & & $\begin{array}{l}\text { Žr. publikaciją „Kongresas } \\
\text { reikalauja informacijos } \\
\text { apie slaptus D. Trumpo ir } \\
\text { V. Putino pokalbius“. }\end{array}$ \\
\hline
\end{tabular}




\begin{tabular}{|c|c|c|}
\hline $\begin{array}{l}\text { Straipsnio / informacijos / } \\
\text { pranešimo šaltinis, pavadini- } \\
\text { mas, internetinė nuoroda ir } \\
\text { paskelbimo data }\end{array}$ & Citata & $\begin{array}{l}\text { Semantinès ir prasmi- } \\
\text { nès V. Putino naratyvo } \\
\text { nuorodos }\end{array}$ \\
\hline $\begin{array}{l}\text { BNS, APF, Lrytas.lt inf. } \\
\text { Kongresas reikalauja informa- } \\
\text { cijos apie slaptus D. Trumpo ir } \\
\text { V. Putino pokalbius } \\
\text { https://www.lrytas.lt/pasaulis/ } \\
\text { ivykiai/2019/03/05/news/ } \\
\text { av-demokratai-reikalau- } \\
\text { ja-informacijos-apie-slap- } \\
\text { tus-d-trumpo-ir-v-putino- } \\
\text { pokalbius-9462690/?utm_- } \\
\text { source=lrExtraLinks\&utm_- } \\
\text { campaign=Copy\&utm_ } \\
\text { medium=Copy } \\
2019 \text { m. kovo } 5 \text { d. }\end{array}$ & $\begin{array}{l}\text { „Remiantis žinias- } \\
\text { klaidos pranešimais, } \\
\text { prezidentas D. Trum- } \\
\text { pas, regis, ne kartą } \\
\text { ėmėsi žingsnių nuo } \\
\text { kitų administracijos } \\
\text { pareigūnų, Kongreso } \\
\text { ir Amerikos žmonių } \\
\text { nuslèpti savo kontaktų } \\
\text { su prezidentu Putinu } \\
\text { detales“, - rašoma ben- } \\
\text { drame trijų komitetų } \\
\text { pirmininkų Adamo } \\
\text { Schiffo, Ellioto Engelo } \\
\text { ir Elijah Cummingso } \\
\text { pareiškime. }\end{array}$ & $\begin{array}{l}\text { Neskaidrus. } \\
\text { Veiksmažodis nuslepti yra } \\
\text { neigiamos semantikos. }\end{array}$ \\
\hline $\begin{array}{l}\text { Lrytas.lt. } \\
\text { A. Lukašenka sutiko su V. Putino } \\
\text { pasiūlymu - tegul būna rublis } \\
\text { https://www.lrytas.lt/verslas/ } \\
\text { mano-pinigai/2019/03/01/ } \\
\text { news/a-lukasenka-sutiko-su-v- } \\
\text { putino-pasiulymu-tegul-buna- } \\
\text { rublis--9419807/ } \\
2019 \text { m. kovo } 1 \mathrm{~d} .\end{array}$ & & $\begin{array}{l}\text { V. Putino vertinimo atžvil- } \\
\text { giu informacija nekono- } \\
\text { tuota. }\end{array}$ \\
\hline $\begin{array}{l}\text { Lrytas.lt. } \\
\text { JAV pradeda tyrimą - mègins } \\
\text { atskleisti visus slaptus V. Puti- } \\
\text { no ryšius ir turtus } \\
\text { https://www.lrytas.lt/pasaulis/ } \\
\text { ivykiai/2019/02/28/news/ } \\
\text { jav-pradeda-tyrima-megins-at- } \\
\underline{\text { skleisti-visus-slaptus-v-putino- }} \\
\frac{\text { rysius-ir-turtus- } 9411827 /}{2019 \text { m. vasario } 28 \mathrm{~d} \text {. }}\end{array}$ & $\begin{array}{l}\text { „Mes turime nutrauk- } \\
\text { ti šydą nuo klausimo, } \\
\text { kaip jis [V. Putinas - } \\
\text { JZ pastaba] uždirba } \\
\text { pinigus, - kalbėjo } \\
\text { B. Bruenas. - Tai yra } \\
\text { kritinis klausimas } \\
\text { norint suprasti tai, kas } \\
\text { motyvuoja Rusijos } \\
\text { veiksmus. Tai taip pat } \\
\text { parodys Rusijos žmo- } \\
\text { nems, koks korupcijos } \\
\text { lygis vyrauja šalyje } \\
\text { ir kiek turtų turi oli- } \\
\text { garchai, kol paprasti } \\
\text { žmones skursta.“ }\end{array}$ & $\begin{array}{l}\text { Neskaidrus oligarchas, } \\
\text { skurdinantis kitus žmones. } \\
\text { Žodžiai korupcijos lygis ir } \\
\text { skursti turi labai neigiamą } \\
\text { konotaciją. }\end{array}$ \\
\hline
\end{tabular}




\begin{tabular}{|c|c|c|}
\hline $\begin{array}{l}\text { Straipsnio / informacijos / } \\
\text { pranešimo šaltinis, pavadini- } \\
\text { mas, internetinė nuoroda ir } \\
\text { paskelbimo data }\end{array}$ & Citata & $\begin{array}{l}\text { Semantinès ir prasmi- } \\
\text { nès V. Putino naratyvo } \\
\text { nuorodos }\end{array}$ \\
\hline III. $\quad$ www. $15 \mathrm{~min} . \mathrm{lt}$ & www. $15 \mathrm{~min} .1 \mathrm{tt}$ & www. $15 \mathrm{~min} .1 \mathrm{t}$ \\
\hline $\begin{array}{l}\text { Šaltinis - partnerio turinys. } \\
\text { Filmas apie V. Putino atèjimą } \\
\text { ì valdžią - autentiški kadrai, } \\
\text { kuriais sunku patiketti } \\
\text { https://www.15min.lt/ } \\
\text { kultura/naujiena/kinas/ } \\
\text { filmas-apie-v-putino-atejima- } \\
\text { i-valdzia-autentiski-kadrai-ku- } \\
\text { riais-sunku-patiketi-4-1123770 } \\
2019 \text { m. kovo 31 d. }\end{array}$ & & $\begin{array}{l}\text { V. Putino vertinimo atžvil- } \\
\text { giu informacija nekono- } \\
\text { tuota. }\end{array}$ \\
\hline $\begin{array}{l}\text { BNS. } \\
\text { Estijos prezidentė per kelionę i } \\
\text { Rusiją nori susitikti su Vladi- } \\
\text { miru Putinu } \\
\text { https://www.15min.lt/ } \\
\text { naujiena/aktualu/pasaulis/ } \\
\text { estijos-prezidente-per-kelione- } \\
\text { i-rusija-nori-susitikti-su-vladi- } \\
\text { miru-putinu-57-1124856 } \\
\text { Publikacija nedatuota, chrono- } \\
\text { loginejje paieškoje pateikiama } \\
\text { tarp } 2019 \text { m. kovo } 31 \mathrm{~d} \text {. ir } 27 \mathrm{~d} \text {. }\end{array}$ & & $\begin{array}{l}\text { Žr. komentarus apie tokią } \\
\text { pačią publikaciją Delfi.lt } \\
\text { portale. }\end{array}$ \\
\hline $\begin{array}{l}\text { BNS. } \\
\text { P. Porošenka - V. Putinas vie- } \\
\text { nintelis mano oponentas } \\
\text { https://www.15min.lt/naujiena/ } \\
\text { aktualu/pasaulis/p-porosenka- } \\
\text { v-putinas-vienintelis-mano- } \\
\text { oponentas-57-1121838 } \\
2019 \mathrm{~m} . \text { kovo } 27 \mathrm{~d} .\end{array}$ & & $\begin{array}{l}\text { Žr. komentarus apie tokią } \\
\text { pačią publikaciją Delfi.lt } \\
\text { portale. }\end{array}$ \\
\hline
\end{tabular}




\begin{tabular}{|c|c|c|}
\hline $\begin{array}{l}\text { Straipsnio / informacijos / } \\
\text { pranešimo šaltinis, pavadini- } \\
\text { mas, internetinė nuoroda ir } \\
\text { paskelbimo data }\end{array}$ & Citata & $\begin{array}{l}\text { Semantinès ir prasmi- } \\
\text { nès V. Putino naratyvo } \\
\text { nuorodos }\end{array}$ \\
\hline $\begin{array}{l}\text { Šaltinis nenurodytas. } \\
\text { Šalia D. Trumpo ịamžintas } \\
\text { „mažylis“ V. Putinas ypatingai } \\
\text { prajuokino rusu internautus“ } \\
\text { https://www.15min.lt/verslas/ } \\
\text { video/salia-dtrumpo-iamzin- } \\
\underline{\text { tas-mazylis-vputinas-prajuoki- }} \\
\text { no-rusu-internautus-148458 } \\
\text { Multimedijų žinutė nedatuota, } \\
\text { chronologinèje paieškoje patei- } \\
\text { kiama tarp } 2019 \text { m. kovo } 27 \text { ir } \\
\text { kovo } 27 \text { d. }\end{array}$ & $\begin{array}{l}\text { Savaitgalị Paryžiuje } \\
\text { vykusiame Pirmojo } \\
\text { pasaulinio karo } \\
\text { pabaigos minejime } \\
\text { šalia JAV prezidento } \\
\text { Donaldo Trumpo } \\
\text { jamžintas Vladimiras } \\
\text { Putinas prajuokino } \\
\text { internautus: jie èmė } \\
\text { dalytis fotomontažais, } \\
\text { kuriuose jų preziden- } \\
\text { tas - gerokai žemesnis } \\
\text { nei realybeje. }\end{array}$ & $\begin{array}{l}\text { Žemaūgis. } \\
\text { Vyro žemas ūgis vertinamas } \\
\text { neigiamai ir turi ịvairių } \\
\text { sociokultūrinių konotacijų. } \\
\text { Dar žemesnis - nepagarbi } \\
\text { nuorodą i žemą V. Putino } \\
\text { ūgị. }\end{array}$ \\
\hline $\begin{array}{l}\text { BNS. } \\
\text { Rusijos prezidentas V. Putinas } \\
\text { pasirašè melagingas naujienas } \\
\text { draudžiantị istatymą. } \\
\text { https://www.15min.lt/naujiena/ } \\
\text { aktualu/pasaulis/rusijos-prezi- } \\
\text { dentas-v-putinas-pasirase-me- } \\
\underline{\text { lagingas-naujienas-draudzian- }} \\
\text { ti-istatyma-57-1117720 } \\
2019 \text { m. kovo } 18 \mathrm{~d} .\end{array}$ & & $\begin{array}{l}\text { Žr. komentarus apie tokią } \\
\text { pačią publikaciją portale } \\
\text { Lrytas.lt. }\end{array}$ \\
\hline $\begin{array}{l}\text { BNS. } \\
\text { V. Putinas lankosi prieš } \\
\text { penkerius metus aneksuotame } \\
\text { Kryme } \\
\text { https://www.15min. } \\
\text { lt/naujiena/aktualu/ } \\
\text { pasaulis/v-putinas-lankosi- } \\
\text { pries-penkerius-metus-anek- } \\
\text { suotame-kryme-57-1117750 } \\
2019 \text { m. kovo } 18 \mathrm{~d} \text {. }\end{array}$ & & $\begin{array}{l}\text { Žr. komentarus apie tokią } \\
\text { pačią publikaciją portale } \\
\text { Lrytas.lt. }\end{array}$ \\
\hline
\end{tabular}




\begin{tabular}{|c|c|c|}
\hline $\begin{array}{l}\text { Straipsnio / informacijos / } \\
\text { pranešimo šaltinis, pavadini- } \\
\text { mas, internetinė nuoroda ir } \\
\text { paskelbimo data }\end{array}$ & Citata & $\begin{array}{l}\text { Semantinès ir prasmi- } \\
\text { nès V. Putino naratyvo } \\
\text { nuorodos }\end{array}$ \\
\hline $\begin{array}{l}\text { BNS. } \\
\text { V. Putinas ketina Kryme } \\
\text { paminèti pusiasalio aneksijos } \\
\text { penktąsias metines } \\
\text { https://www.15min.lt/naujiena/ } \\
\text { aktualu/pasaulis/v-putinas-ke- } \\
\text { tina-kryme-pamineti-pusiasa- } \\
\text { lio-aneksijos-penktasias-meti- } \\
\text { nes-57-1117152 } \\
2019 \text { m. kovo } 17 \text { d. }\end{array}$ & & $\begin{array}{l}\text { Žr. komentarus apie tokią } \\
\text { pačią publikaciją portale } \\
\text { Lrytas.lt. }\end{array}$ \\
\hline $\begin{array}{l}\text { Thomas Reuter. } \\
\text { Vladimiras Putinas atvyko i̇ } \\
\text { Teherano dujų konferenciją } \\
\text { https://www.15min.lt/ } \\
\text { pasaulis-kiseneje/video/vladi- } \\
\text { miras-putinas-atvyko-i-tehera- } \\
\text { no-duju-konferencija-35681 } \\
\text { Multimedijų žinutè nedatuota, } \\
\text { chronologineje paieškoje patei- } \\
\text { kiama tarp 2019 m. kovo } 17 \mathrm{~d} \text {. } \\
\text { ir vasario } 28 \mathrm{~d} \text {. }\end{array}$ & & $\begin{array}{l}\text { V. Putino vertinimo atžvil- } \\
\text { giu informacijos nera. }\end{array}$ \\
\hline
\end{tabular}




\title{
IDEOLOGICAL MECHANISMS OF RUSSIAN \\ FEDERATION PRESIDENT V. PUTIN NARRATIVE IN LITHUANIAN ONLINE MEDIA
}

\author{
JOLANTA ZABARSKAITE்
}

\section{Summary}

Keywords: functions of language; semantic processes; narrative; hybrid war; new media; online media, ideological implications.

This article discusses semantic language processes that can influence the perception and appreciation of one or another phenomenon, process, personality. This work examines the problem of language and thinking relationship, the role of language in shaping the worldview, altered and differently organized language functions in the 21st century and possible use of language semantic processes in hybrid. The question is whether it is possible to recognize an unconscious and/or semi-conscious phenomenon of language comprehension when the semantic mechanisms of word meanings and associations create ideological implications that can influence the evaluation of phenomenon, personality, and event. The language narrative and its correction mechanisms are discussed in the context of ideological implications. The mass media have been chosen to reveal the semantic mechanisms of ideological implications as it is the most critical space in the public language. The case study has been performed in this work. The role of lexis and semantics in the creation of narratives about Vladimir Putin - the president of Russia, an important geopolitical neighbor of Lithuania was studied using data from large Lithuanian new portals: $w w w . d e l f i . l t, w w w . l r y t a s . l t$, www.15min.lt.

Iteikta 2019 m. balandžio 19 d. 